\title{
EXPORTING WESTERN LAW TO THE DEVELOPING WORLD: THE TROUBLING CASE OF NIGER
}

\section{Introduction}

In recent decades the West ${ }^{1}$ has imposed on the Developing World the so-called Washington Consensus, a package of policy reforms that, if implemented properly, is supposed to propel poor countries toward First World prosperity. ${ }^{2}$ In the United States, popular accounts of the Consensus focus on its economic policies and their social consequences. The usual story is that Western countries and the financial institutions they control, most notably the World Bank and the International Monetary Fund, insist that a given poor country implement policies of privatization and trade liberalization. The poor country's government, having little choice in the matter, begins to comply with these "structural adjustment" initiatives, which leads to protests and general social unrest when the citizenry realizes, among other things, that the price of bread has doubled overnight. $^{3}$

\footnotetext{
${ }^{1}$ I use the term West to refer generally and inexactly to those countries, primarily though not exclusively in North American and Europe, that control most of the world's wealth and thereby have the means to exert political dominance over the rest of the world. This inexact group also goes by the name of the First World, Developed Countries and the Global North.

${ }^{2}$ See Ali Zafar, Revenue and the Fiscal Impact of Trade Liberalization: The Case of Niger 4 (World Bank Policy Research Working Paper 3500, February 2005) (noting that standard trade theory suggests that trade liberalization leads to more efficient allocation of resources, enhanced productivity, and higher economic growth); REPUBLIC OF NIGER, OFFICE OF THE PRIME MINISTER, POVERTY REDUCTION STRATEGY 69 (January 2002) (referring to the role of law reform in creating a "favorable investment climate"); James Gathii, Human Rights, The World Bank and the Washington Consensus: 1949-1999, 94 AM. SOC'Y INT'L L. PROC. 144, 145 (April, 2000) (stating that the World Bank views its Washington Consensus reforms as an "engine of growth" for developing economies); Michel Chossudovsky, THE GLOBALIZATION OF POVERTY: IMPACTS OF IMF AND WORLD BANK REFORMS 17 (1997). ${ }^{3}$ See, e.g., Jon Jeter, The Dumping Ground: As Zambia Courts Western Markets, Used Good Arrive at a Heavy Price, THE WASHINGTON POST, April 22, 2002, at A1 (referring to suffering in Zambia as a result of World Bank economic policies); Nigeria Police Fire on Crowd Protesting Austerity Program, N.Y. TIMES, May 28, 1989, A12 (reporting violent demonstrations in Nigeria over its structural
} 
But there is another important aspect of Consensus reform that we rarely read about in the Western popular press, one that has the potential to create at least as much social unrest: legal reform. The Washington Legal Consensus ${ }^{4}$ holds that poor countries must reshape their legal systems to make them compatible with Western conceptions of law and justice. If they do not, they will fail to attract trade and investment, and will be left out of the long term prosperity made possible by the Consensus economic reforms. ${ }^{5}$

Scholars who have scrutinized the Washington Legal Consensus have found much to criticize. ${ }^{6}$ Some abhor that Consensus reformers impose new laws and legal concepts after minimal consultation with the affected populations. ${ }^{7}$ Others find it troubling that educated elites within poor countries tend to use Consensus legal reforms to consolidate their economic and political power. ${ }^{8}$ Many observe that the hoped-for economic benefits

adjustment program); Charles Derber, Op-Ed., Will the World be Ruled By Money or Human Rights?, THE BOSTON GLOBE, April 15, 2000, at A15 (referring to structural adjustment bread riots "from Caracas to Jakarta").

${ }^{4}$ To the best of my knowledge, no commentator has used the term Washington Legal Consensus. I will adopt it in this paper and assume that its meaning is self-explanatory.

${ }^{5}$ See THE WORLD BANK, MEMORANDUM OF THE PRESIDENT OF THE INTERNATIONAL DEVELOPMENT ASSOCIATION TO THE EXECUTIVE DIRECTORS ON A COUNTRY ASSISTANCE STRATEGY OF THE WORLD BANK FOR THE REPUBLIC OF NIGER 4 (January 21, 2003)(identifying a weak and understaffed judicial system as a key barrier to economic development); REPUBLIC OF NIGER, OFFICE OF THE PRIME MINISTER, POVERTY REDUCTION STRATEGY 65, 69 (January 22, 2002) (stating that "strengthening and consolidating the state of law" is vital to poverty reduction).

${ }^{6}$ See generally Yves Dezalay \& Bryant G. Garth, Introduction to THE INTERNATIONALIZATION OF PALACE WARS: LAWYERS, ECONOMISTS AND THE CONTEST TO TRANFORM LATIN AMERICAN STATES 3 (Yves Dezalay \& Bryant G. Garth, eds., 2002); Heinz Klug, Hubrid(ity) Rules: Creating Local Law in a Globalized World, in GLOBAL PRESCRIPTIONS: THE PRODUCTION, EXPORTATION, AND IMPORTATION OF A NEW LEGAL ORTHODOXY 278-279 (Yves Dezalay \& Brant G. Garth, eds., 2002); see also Alkash Alhada, Les Principes Generaux, in LES DROITS DE L'HOMME AU NIGER: THEORIES ET REALITES 79 (Theodore Holo ed., 2001) (suggesting that Niger's adoption of Western human rights laws is merely a "charm offensive" directed at donor countries). ${ }^{7}$ See Terrence Halliday, CROSSING OCEANS, SPANNING CONTINENTS: EXPORTING EDELMAN TO GLOBAL LAWMAKING AND MARKET-BUILDING, 38 LAW \& SOC'Y REV. 213, 217 (June 2004).

${ }^{8}$ See Paul H. Brietzke, The Politics of Legal Reform, WASH. U. GLOBAL STUD. L. REV. 1, 5-7 (2004) (arguing that elites tend to gain in power and influence through the process of structural adjustment and legal reform); see also Klug, supra note 6, at 280. 
of legal reform rarely materialize. ${ }^{9}$ Few scholars, however, have offered a detailed look at how the Washington Legal Consensus actually plays out on the ground in developing countries, and how it affects the lives of ordinary people living there.

This paper will attempt to fill that gap by examining the particular case of Niger, an especially poor and isolated country that is in the midst of Consensus-inspired law reform. It will describe the law that most contemporary Nigeriens rely on to resolve their day-to-day disputes, and will conclude that Consensus-mandated legal reforms, which are grounded in liberal Western conceptions of law and justice, are so fundamentally different from the law and justice that people live by day-to-day, that the attempt at abrupt reform will cause significant social dislocation.

\section{A. Organization of the Paper}

On the theory that most readers are unfamiliar with traditional Nigerien law or anything like it, the paper will open in Part I.B with a brief descriptive example, leaving analysis of that law for later. Part II will provide a summary description of the Washington Legal Consensus and its application in Niger. Part III will furnish the reader with necessary background on Niger, including a general description its law from the opposite perspectives of Niger's government and its ordinary citizens. Because the law that most Nigeriens live by is inexorably connected with their history and religion, those topics also will be touched upon. In Part IV, the paper will take a turn into legal ethnography, discussing concrete examples of the spiritually influenced, magic-infused, traditional law that the majority of Niger's people live by, and highlighting some of the fundamental differences between this law and that which the Washington Legal Consensus seeks to impose. Part V will conclude the paper by positing that trouble is in

\footnotetext{
${ }^{9}$ Brietzke, supra note 8, at 17; see Zafar, supra note 2, at 8-10, 20.
} 
store for Niger if it continues to follow the Consensus-mandated path it is on, and suggesting some alternative approaches that might facilitate the development of Niger's legal system without throwing the country into turmoil.

B. First example of Nigerien traditional law: the gon oracle informs a man which of his two wives has been stealing from him. ${ }^{10}$

It is midmorning in the Zongo ${ }^{11}$ neighborhood of Niger's capital, Niamey. A crowd of agitated people gathers at the family home of the Sarkin of Zongo, the traditional chief whose clan has reigned over this area of town since the early $20^{\text {th }}$ century. The people, perhaps twenty of them, are squeezed into a narrow dirt walkway between two mud buildings and they are arguing about thefts. A man - well educated and prosperous by Nigerien standards - is at the center of the throng. He tells the Sarkin that he is sure that one of his two wives, both of whom are present, has been stealing from him. In the recent past, money, valuable clothing, and expensive prayer rugs have disappeared from his home, and he has had enough. He has brought them to the Sarkin, who, he knows, can perform the gon, an oracle that will reveal which of his wives is guilty.

\footnotetext{
${ }^{10}$ All of the events described in this vignette are based on Zongo Field Notes 00001, Niamey, Republic of Niger (February 18, 2004). Part IV.A., below, describes the methodology I employed in studying traditional Nigerien law.

${ }^{11}$ Zongo is a word of Hausa origin that describes neighborhoods where outsiders settle. Typically, Muslim traders established Zongo neighborhoods on the outskirts of existing cities and towns. Historically, Zongo neighborhoods were centers of both trade and Islamic piety. Today, there are Zongo neighborhoods throughout West Africa and the Western Sudan. See Allan Christelow, Islamic Law in Africa, in HISTORY OF ISLAM IN AFRICA 379 (Nihemia Levitzion \& Randall L. Pouwells, eds., 2000); see also Interview with Hamza Maman Bako, Niamey, Republic of Niger (February 6, 2004) (recounting the history of Niamey's Zongo neighborhood).
} 
Because innocence and guilt in traditional Nigerien society apply to whole families, ${ }^{12}$ the mothers, fathers, and assorted siblings of both wives are present to witness the gon. The aggrieved husband takes the lead in describing the thefts to the Sarkin, but the family members constantly and loudly intervene with additional facts, clarifications, and challenges.

The crowd also includes several men and women of various ages from the neighborhood around the Sarkin's compound. They have come to watch the show, for although the reading ${ }^{13}$ of the gon is an everyday event in Zongo, ${ }^{14}$ the dispute today is more heated and therefore more interesting than usual.

There also are two young boys lingering on the periphery of the tumult. One of them holds two reeds, each about two feet long, in his hand. The other boy holds an ornate, gold-embossed copy of the Koran in one hand and a rolled, tattered plastic prayer mat in the other. Both boys periodically make eye contact with a tall, thin man who stands off to the side, out of the fray. He is the marabout, the religious leader who will read the words that will give power to the gon oracle.

When the Sarkin of Zongo has heard enough from the man, his wives, and their assorted family members, he quiets the crowd and says it is time to consult the oracle. As

\footnotetext{
${ }^{12}$ See, supra Part III.D.2; Thomas Kelley, Squeezing Parakeets into Pigeon Holes: The Effects of Globalization and State Legal Reform in Niger on Indigenous Zarma Law, 34 NYU JOURNAL OF INTERNATIONAL LAW AND POLITICS 635, 677 (Spring 2002); see also REPUBLIC OF NIGER, MISSION D'ANALYSE ET DE FORMULATION DU CADRE GENERAL DU PROCESSUS DE REFORMES ET DU PROGRAMME D'APPUI AUX REFORMES JUDICIARES AU NIGER (PARJ) KR-1994 26 (February 2003) [hereinafter Mission d'Analyse] (stating that Niger's traditional conception of law applies to collectivities rather than individuals).

${ }^{13}$ Whereas in English we would use the verb "perform," as in, "the marabout performed the gon," Nigeriens invariably use the verb "read" (in Zarma, caw). As described in the present section of the paper and in Part IV.B.1, below, reading from the Koran is an important element of the oracle. Further, Nigeriens may favor the verb read because they generally associate the written word and reading with mystical power such as that exhibited by the gon oracle. See Ladislav Holy, RELIGION AND CUSTOM IN A MUSLIM SOCIETY, THE BERTI OF SUDAN 10 (1991).

${ }^{14}$ Interview with Hamza Maman Bako, supra note 11.
} 
the parties and the observers settle in, the two young boys who were lingering on the fringe walk to the center of the room to assume their roles in the gon. They hand the Koran to the marabout and then roll out the plastic prayer mat. They kneel on the mat facing one another, about two feet apart, and peel off their shirts. Each boy places the ends of the reeds between his thumbs and forefingers, and raises them toward his nipples. As they wait for the Sarkin and the marabout to proceed, they hold the reeds between their chests, forming a rectangle in which the reeds are parallel to one another about eight inches apart.

The Sarkin stands beside the kneeling boys and explains to all present that in order to arrive at the full truth he must name each of the items stolen, and, for each such item, ask each wife to submit to the gon oracle. He announces that the first item tested will be the husband's missing clothing. He directs the senior wife to stand next to him, then leads her through an oath that focuses the gon's revelatory powers solely on the stolen clothing (ensuring that it does not react to some other wrong she has committed), and states that if she is guilty, the reeds will bend toward her hand and "trap" her.

The Sarkin then instructs the senior wife to bend over and place her hand between the two reeds. As she does so, the two boys place the ends of the reeds against their nipples and, leaning slightly toward one another, suspend them between their chests. At the instant the wife lowers her hand, the marabout, who is sitting in the corner, begins to chant the yassina, a verse from the holy Koran. Almost immediately the reeds begin to wobble, and then bow definitively outward, indicating that the senior wife is innocent of stealing the clothing. The junior wife is then called to submit to the same procedure. 
This time, the reeds bow inward, indicating that she is guilty. She does not protest her innocence; she simply walks back to her place and waits for her next turn.

In this fashion, the Sarkin proceeds methodically through the list of stolen items. The gon reveals that the junior wife stole the clothing and the money, while the senior wife stole the expensive prayer rugs. When the gon is complete, both wives admit before their families and the gathered crowd that they have been justly found guilty of their wrongs. The Sarkin, the marabout, and the fathers of both wives huddle together for a quick consultation and agree that the husband and his wives should return immediately to their community and gather together the elders to attempt to negotiate peace among the family members and find a way by which they can continue to live together.

\section{The Washington Consensus}

\section{A. The Consensus in General}

The primary impetus for Niger's current state law reform project comes from the Washington Legal Consensus. ${ }^{15}$ While it is true that western-educated urban elites ${ }^{16}$ and some rural elites ${ }^{17}$ express enthusiasm for legal westernization, the push has come primarily from donor countries and the financial institutions they control. ${ }^{18}$

\footnotetext{
${ }^{15}$ Interview with Oumarou Rabo Mainassara, Director of Study of Legislative Reform and Integration, Niger Ministry of Justice, Niamey, Republic of Niger (November 23, 2003) (stating the World Bank and donor countries are behind the push for law reform); see Jurgen Kurtz, Comment to Professor Stephen D. Krasner in symposium entitled Diversity or Cacophony?: New Sources of Norms in International Law, MICH. J. INT'L L. 1103, 1104 (Summer 2004)(referring to the West's insistence upon legal reform in poor countries); Klug, supra note 3, at 278 (employing the term "global insistence" to refer to the West's push for legal reform in the developing world).

${ }^{16}$ See, e.g., Interview with Niger's Permanent Secretary of the Rural Code, Niamey, Republic of Niger, (November 10, 2003) (expressing the view that law reform is necessary because traditional law is corrupt and inefficient).

${ }^{17}$ Traditional chiefs tend to solidify their control of land and other valuable resources when western laws are introduced and enforced. See Paul H. Brietzke, supra note 8, at 5-7 (arguing that elites tend to gain in power and influence through the process of structural adjustment and legal reform); see also Shem E. Migot-Adholla \& John Bruce, Are Indigenous African Tenure Systems Insecure?, in SEARCHING FOR LAND TENURE SECURITY IN AFRICA 1, 9 (Shem E. Migot-Adholla \& John Bruce eds., 1994) (arguing that studies have shown that elites took advantage of land tenure reform in Kenya to enrich
} 
In general, the Consensus holds that economic and social development (the theory assumes that the latter inevitably follows the former) are possible only if poor countries privilege the market as the locus of economic decision making. ${ }^{19}$ Accordingly, it calls for reducing social spending and reallocating resources to the private sector, ${ }^{20}$ budgetary austerity, trade liberalization and privatization, ${ }^{21}$ and privatization of agricultural land. ${ }^{22}$

The legal part of the Consensus requires poor countries to reform their laws as a means of permitting the prosperity promised by the Consensus economic policies. Under the rubric of good governance, it requires transparency, consistency, and predictability of laws to provide would-be investors with a stable and inviting governmental and legal framework in which to do business. ${ }^{23}$

Poor countries often have little choice in the matter of reform. The World Bank and the International Monetary Fund, along with other multilateral financial institutions and bilateral donor countries, dole out money to poor countries in the form of "policy based loans" that contain so called "conditionalities." 24 These conditionalities state, in essence, that the poor countries do not get the money unless their governments comply

themselves); Kelley, supra note 12, at 684 (recounting an episode where an elder, elite, rural Nigerien sold land out from under his extended family's control).

${ }^{18}$ See Michael Chossudovsky, supra note 2, at 16 (arguing that the power of the Bretton Woods organizations lies with their majority shareholders who are the governments of the world's rich countries).

${ }^{19}$ Gathii, supra note 2, at 145 .

${ }^{20} I d$.

${ }^{21}$ Chossudovsky, supra note 2, at 35 .

${ }^{22} I d$. at 67.

${ }^{23}$ Brietzke, supra note 8, at 4; see also Yves Dezalay \& Bryant G. Garth, Introduction to GLOBAL PRESCRIPTIONS, supra note 6, at 1; Kurtz, supra note 15, at 1104; Sally Engle Merry, From Law and Colonialism to Law and Globalization: Martin Chanook. Law, Custom, and Social Order: The Colonial Experience in Malawi and Zambia, 28 LAW \& SOC. INQUIRY 569, 570 (arguing rule of law and judicial reforms are motivated by economic considerations such as the need to establish a legal infrastructure for investment and trade as countries all over the world strive "to become valued members of the so-called international community"); Mission d'Analyse, supra note 12, at 107 (offering the Government of Niger's articulation of the connection between legal reform and economic development).

${ }^{24}$ Chossudovsky, supra note 2, at 51 . 
fully with the pre-packaged economic and legal reforms. ${ }^{25}$ We will discuss below how

Niger is faring as a result of its submission to the Consensus, but it is not giving away too

much now to say that, in general, the track record of these externally inspired reforms, including the law reform project, has been poor. ${ }^{26}$

\section{B. The Legal Consensus in Niger}

It is beyond the scope of this paper to offer a detailed description of Niger's externally developed plans for economic and legal reform. As to economic reform, it must suffice to say that the plan is roughly in accord with the general description of the Consensus provided above, ${ }^{27}$ and that thus far it has caused pain and consternation among Niger's people and little if anything in the way of beneficial economic development. ${ }^{28}$ The law reform aspects of the plan are somewhat more difficult to discern, because there is no single World Bank or IMF document that sketches its

\footnotetext{
${ }^{25} I d$. at 51-52 (adding that countries that decline to comply with the structural adjustment dictates of the Bretton Woods organizations find themselves cut off not only from their economic largess, but from grants and loans by other multilateral and bilateral sources of funds in the West); see also Kurtz, supra note 15, at 1105 (arguing that international financial institutions controlled by the West force developing countries to sign off on law reform plans by threatening to withhold desperately needed financial support).

${ }^{26}$ See Dezalay \& Garth, supra note 23, at 2 (arguing that the new "rule of law industry" cannot claim many successes); see also Zafar, supra note 2, at 4, 20 (concluding that the World Bank inspired structural adjustment program for Niger, particularly its trade liberalization program, has caused significant fiscal damage without spurring increased trade).

${ }^{27}$ See generally REPUBLIC OF NIGER, OFFICE OF THE PRIME MINISTER, POVERTY REDUCTION STRATEGY (January 2002) (laying out the long term poverty reduction plan developed by the IMF and the Government of Niger).

${ }^{28}$ See Zafar, supra note 2, at 4, 20 (concluding that the World Bank inspired structural adjustment program for Niger, particularly its trade liberalization program, has caused significant fiscal damage without spurring trade); see also Maman Abou, La grogne . . , LE REPUBLICAIN, March 17-23, 2005, at 1 (reporting popular discontent over IMF fiscal policy); Mahamadou Diallo, Tenailles par la Misere, 60,000 Manifestatns dans les Rues de Niamey, LE REPUBLICAIN, March 17-23, 2005, at 4 (same); S.A., Gigantesque Manifestation a Niamey Contre la Vie Chere, LE DEMOCRATE, March 17, 2005, at 1, 4-5 (reporting demonstrations and offering a critique of IMF fiscal policy); Interview with the Director of the Project Supporting Good Governance and the Promotion of the Private Sector, Ministry of Finance, Niamey, Republic of Niger (February 24, 2004) (saying "good governance" has developed slowly in Niger because of the hardship and social unrest caused by structural adjustment).
} 
contours. ${ }^{29}$ We therefore must rely at least partly on newspaper accounts, interviews with government officials, and speculation.

Since1999, the year in which Niger's most recent military dictator was ejected and the country launched into its first sustained period of democratic governance, the pace of legal reform has been blinding. ${ }^{30}$ Its leaders have passed a new Constitution, an Electoral Code, a Criminal Code, a Code of Criminal Procedure and a surfeit of international treaties and lesser bits of legislation. ${ }^{31}$ In addition, it drafted and debated (but did not pass) a controversial Family Code, and is rumored to be on the verge of passing a new Code of Civil Procedure. ${ }^{32}$

Given the rapidity of the reform effort, it should not come as a surprise that many of the new laws whizzed by without opportunities for significant debate or reflection about their impact on Nigerien society. ${ }^{33}$ They were drafted mostly by outside experts ${ }^{34}$

\footnotetext{
${ }^{29}$ There is, however, the Mission d'Analyse, introduced in note 12, above. It lays out a comprehensive program for reforming Niger's judicial system. It was funded by Danish, German, and French development organizations and was written for the Government of Niger by a European consulting organization. The World Bank has declared that its intention is to leave the details of law reform in Niger up to donor countries with Denmark as the leader. See THE WORLD BANK, MEMORANDUM OF THE PRESIDENT, supra note 5, at 10-11.

${ }^{30}$ Niger's law reform efforts actually began gradually in the 1970s with an effort to Westernize land law. Through much of the 1970s and 80s the World Bank pushed freehold land titling as an essential precursor to economic growth in the developing world, including Niger. Interview with Oumarou Rabo Mainassra, supra note 15 (expressing the view that the World Bank and Western donor countries pressured Niger to undertake land law reform); see generally WORLD BANK, LAND REFORM (Policy Paper No. 11018, May 1975), available at http://wwwwds.worldbank.org/servlet/WDS_Ibank_Servlet?pcont=details\&eid=00178330 98101911122064. With funding and technical expertise from the West, Niger embarked on an ambitious effort - one that continues to this day - to shift land from traditional, often communal, control to something like a uniform system of freehold titling. While there is no evidence that the Western land reforms have spurred economic investment, there is ample evidence that they have caused instability in the form of violent struggle over title to formerly communal land and land-grabbing by rural elites. See generally Christian Lund, LAW, POWER AND POLITICS IN NIGER: LAND STRUGGLES AND THE RURAL CODE (1998).

${ }^{31}$ The lesser legislation includes the laws governing the National Assembly, the decentralization of Niger's government, non-governmental organizations and domestic associations, magistrates, and the legal profession.

${ }^{32}$ See Mission d'Analyse, supra note 12, at 64 (discussing the need for a Civil Procedure Code).

${ }^{33}$ See Brietzke, supra note 8, at 22 (arguing that Western legal reformers' desire to "get things done quickly" leads them to implant reforms that are "rushed, poor in quality, and unimplemented or unimplementable").
} 
and rushed through Niger's National Assembly, a newly created legislative body in which a significant percentage of representatives neither speak nor read French, the language in which the laws were written. ${ }^{35}$ Another, very much longer, article would be required to review the contents of this bonanza of newly reformed laws, but for our limited purposes we can say that in most fundamental respects, they are like the laws of the United States and Western Europe: they emphasize the protection of individual rights, due process, rational proof, and the individual punishment and deterrence of anti-social acts.

The new Criminal and Criminal Procedure Codes can stand in as representative examples of the Consensus-inspired reforms. ${ }^{36}$ We focus on them partly for the simple reason that I was able to obtain written copies of their texts ${ }^{37}$ and partly because they provide a tidy comparison with the traditional law that we explore in Parts I.B, above, and IV.B.1, below.

For our purposes, the most significant change to the new Criminal Code is the adoption of uncomplicated language to the effect that "no one is criminally responsible

\footnotetext{
${ }^{34}$ See Interview with Oumarou Rabo Mainassra, supra note 15 (the Ministry of Justice official in charge of reviewing new laws stating that his office has no personnel at its disposal and not even an internet connection and cannot possibly give substantive input on all of the laws being passed in Niger).

${ }^{35}$ When I posed the question to Nigerien scholars whether the legislature debated and discussed the impact that this view of justice would have on rural communities, they laughed. In the case of the Penal Code, there was barely time to read the draft before it was passed, and, even if there had been time, a majority of the members of the National Assembly are not fluent in French and cannot read or write their own mother tongues. See Interview with Professor Sidikou Harouna, Niamey, Republic of Niger (November 19, 2003). According to gossip among lawyers in Niamey, the process of drafting and passing the Penal Code was so rushed that the initially passed version had to be withdrawn when judicial officials realized that the country did not have enough jail cells for all the people who would be imprisoned under the new laws. They had to go back and devise provisions for alternatives to incarceration.

${ }^{36}$ The "old" Criminal Code was a wholesale adoption at Independence in 1961 of the French Criminal Code. See Kelley, supra note 12, at 659. For reasons discussed in Part III.D.1, below, its implementation over the years has been spotty at best.

${ }^{37}$ Obtaining printed copies of laws in Niger poses a challenge for the legal scholar. Often, the Western countries who help write the laws pay to have a certain number of copies printed. Officials in the government ministries that are affected by the new laws typically sell their allotted copies to private book dealers who hawk their wares from street side tables. One searching for printed versions of official laws must therefore wander through the capital haggling with the book dealers.
} 
except for by his own acts." ${ }^{38}$ This statement may appear unremarkable and uncontroversial to a Western lawyer, but in fact it was inserted with the intention of effecting a fundamental change in the way Nigeriens view criminal responsibility. Instead of placing responsibility for crimes with families and larger social units, as described in Part III.D.2, below, the new law insists that responsibility for crime (and the attendant punishment) be confined only to the individual wrongdoer.

The newly reformed Criminal Code also attempts to bring Niger into the modern world, and to bring its domestic law into conformity with the many international treaties it has signed since independence, by creating penalties for female genital mutilation, the intentional transmission of HIV, sexual harassment, genocide, war crimes, and the practice of slavery. ${ }^{39}$ In keeping with the World Bank's economic goals, it creates new criminal categories for practices that retard economic progress, such as usury and Internet fraud. $^{40}$

The new Code of Criminal Procedure lays out a scheme that should be familiar to any Western lawyer. It enshrines notions of due process and fair trial. For example, it provides that the criminally accused will have the right to the assistance of counsel. ${ }^{41}$ It further provides procedural guarantees that limit the time and scope of criminal

\footnotetext{
${ }^{38}$ Book I, Title II, Chapter I, Section 1, Article 4 of the Loi no. 2003-25 du 13 juin 2003, modifiant la loi no 61-27 du 15 juillet 1961, portant institution de la code penal, Journal Officiel de la Republique du Niger, December 15, 2003 [hereinafter Loi no. 2003-25] (« Nul n’est responsable pénalement que de son propre fait $\gg)$.

${ }^{39}$ See Book II, Title III, Chapter VI, Section 2, of the Loi no. 2003-25.

${ }^{40}$ See Book II, Title VII of the Loi no. 2003-25; see also H. B. Tcherno, Interviews du Ministre de la Justice: Les Grandes Lignes de la Reforme du Code Penal, 255 Groupe Alternative (July 20, 2001), at http://www.altervative.ne/hebdo/2001/255/p_code.htm.

${ }^{41}$ Book I, Title I, Chapter II, Section III, Article 6 of the Loi no. 2003-26 du 13 juin 2003 modifiant la loi no 61-33 du 14 aout 1961, portant institution du Code de procedure penale, Journal Officiel de la Republique du Niger, December 15, 2003 [hereinafter Loi no 2003-26].
} 
investigations and cut back on the use of pre-trial detention. ${ }^{42}$ It even provides the possibility of financial compensation for those who have been wrongly detained by judicial authorities. ${ }^{43}$ In short, it creates a Western system of criminal procedure based on the assumption that crimes, including theft, are matters to be resolved between individual perpetrators and the state, that responsibility is to be determined through a process of rational fact gathering, followed by impartial trial, leading (at least in some cases) to conviction and punishment in the form of fines and imprisonment.

Although the new Criminal and Criminal Procedure laws do not state so explicitly, they implicitly reject Niger's traditional legal norms. As we will discuss at more length in Part III.D.2, below, the new Codes do not recognize the collective legal responsibility of family members, ${ }^{44}$ do not permit families and larger communities to resolve criminal matters through ad hoc negotiation, ${ }^{45}$ do not provide for reinsertion into the community, ${ }^{46}$ and do not permit the consideration of spiritually determined oracular evidence such as that produced by the gon.

There is another vitally important aspect of Niger's Washington Consensus legal reform that is not revealed anywhere in the text of the laws that are being promulgated. It is the assumption that the modernization of Niger's law requires not only that these new, Western laws be passed, but that they be consistently and uniformly enforced. ${ }^{47}$ Such enforcement is not possible, reformers contend, unless the country's irrational and unpredictable legal traditions, such as reliance on the gon oracle, are eliminated.

\footnotetext{
${ }^{42}$ See, e.g., Title III, Chapter I, Section VIII, Article 31 of the Loi no. 2003-26.

${ }^{43}$ Title III, Chapter I, Section VII, Article 143-1 of the Loi no. 2003-26.

${ }^{44}$ See Tcherno, supra note 40, at p. 6.

${ }^{45}$ Kelley, supra note 12 , at 696.

${ }^{46} I d$.

${ }^{47}$ See Mission d'Analyze, supra note 12, at 45; Tcherno, supra note 40, at p. 6.
} 


\section{Summary}

For Niger, the gist of the Washington Legal Consensus is that if it wishes its economic boat to rise with the tide of global trade, and, in the shorter term, if it wishes to receive financial support from Western countries and the financial institutions they control, it must rapidly reform its legal system to make it look and feel more like legal systems in the West.

We will come back to the Washington Legal Consensus in Part V, below. For now, we turn our attention to a subject that proponents of the Washington Legal Consensus seem consistently to ignore: the culture and the law of the place that is to be westernized; in this case, Niger.

\section{Background on Niger}

Relatively little has been written in English about Niger, ${ }^{48}$ but for our limited purposes we need know relatively little. A few points are of paramount importance. First, it is extremely poor. Second, largely due to that material poverty, it has remained comparatively isolated from the Western world. Third, its spiritual beliefs are complex and unique, and are bound inextricably with what we in the West consider "law." Finally, "law" in contemporary Niger is not what it first might appear.

\section{A. Vital Statistics}

According to the United Nations, Niger is the least developed country in the World. ${ }^{49}$ Approximately four fifths of its landmass is located in the Sahara Desert, and

\footnotetext{
48 See Finn Fuglestad, A HISTORY OF NIGER 1850-1960 (1983); Robert Charlick, NIGER: PERSONAL RULE AND SURVIVAL IN THE SAHEL (1991); Kelley, supra note 12, at 635. ${ }^{49}$ U.N. DEVELOPMENT PROGRAM, HUMAN DEVELOPMENT REPORT 2005 NIGER COUNTRY FACT SHEET (2005), available at hdr.undp.org/statistics/data/country_fact_sheets/cty_fs_NER.html.
} 
only a small percentage of its land is arable. ${ }^{50}$ Niger's population stands at more than 13 million, and its annual population growth rate, at 3.3\%, as well as its fertility rate, at 7.9 live births per woman, are among the highest in the world. ${ }^{51}$ More than a quarter of Nigerien children die before they reach the age of 5, and a child born between 2000 and 2005 has less than a $40 \%$ chance of surviving to the age of $40 .^{52}$ Overall life expectancy is 44 years, which ranks among the lowest in the world. ${ }^{53}$ This truncated average life span is all the more remarkable when one realizes that HIV/AIDs is not prevalent in Niger, and thus is not a major cause of early mortality. ${ }^{54}$

Niger's adult literacy rate is $14 \%$, and only $38 \%$ of eligible children were enrolled in primary school during the 2002-2003 academic year. ${ }^{55}$ Those numbers are markedly lower for Nigerien women, and overall the United Nations ranks Niger last in the world in terms of building the capabilities of women. ${ }^{56}$

Per capita gross domestic product in Niger is $\$ 800$ per year, and $61 \%$ of the population lives off of less than $\$ 1$ per day. ${ }^{57}$ Rural subsistence agriculture, herding, and informal trading activities account for most of the country's meager economic activity. ${ }^{58}$

\footnotetext{
${ }^{50}$ U.S. CENTRAL INTELLIGENCE AGENCY, WORLD FACTBOOK: NIGER (2005), available at http://www.cia.gov/cia/publications/factbook/geos/ng.html (reporting $4 \%$ of land as arable); BUREAU OF AFRICAN AFFAIRS, U.S DEPARTMENT OF STATE, BACKGROUND NOTE: NIGER (March 2005), available at $\mathrm{http}: / / \mathrm{www}$. state.gov/r/pa/ei/bgn/5474.htm (reporting $15 \%$ of land as arable).

${ }^{51}$ U.N. DEVELOPMENT PROGRAMME, HUMAN DEVELOPMENT REPORT 2005 [hereinafter U.N. DEVELOPMENT REPORT 2005].

${ }_{52}$ Id. at _; see also CENTRAL INTELLIGENCE AGENCY, supra note 50.

${ }^{53}$ U.N. DEVELOPMENT REPORT 2005, supra note 51, at

${ }^{54}$ See id. at _ (reporting HIV prevalence at $1.2 \%$ of Niger's population).

${ }^{55} \mathrm{Id}$.

${ }^{56}$ U.N. DEVELOPMENT PROGRAM, HUMAN DEVELOPMENT REPORT 2005 NIGER COUNTRY

FACT SHEET (2005), available at hdr.undp.org/statistics/data/country_fact_sheets/cty_fs_NER.html.

${ }_{58}^{57}$ d.

${ }^{58}$ WORLD BANK, NIGER COUNTRY BRIEF (September 2004), available $a t$ http://web.worldbank.org/WBSITE/EXTERNAL/COUNTRIES/AFRICAEXT/NIGEREXTN/0,,menuPK\% 3A382460 pagePK\%3A141132 piPK\%3A141107 theSitePK\%3A382450,00.html.
} 
Niger's development trend is markedly downward. In the early and mid 1970s the country enjoyed a brief period of relative economic prosperity based upon exploitation of uranium deposits in its northern mountains, but the bottom dropped out of that market in the early 1980s and Niger's economy has been in decline ever since. ${ }^{59}$ Short and long term economic prospects are bleak, as captured by the World Bank's recent, sobering assessment:

Niger's prospects are clouded by a lack of natural resources and a highly degraded natural environment, explosive population growth, extremely low human and institutional capacity, very limited international competitiveness, its location in a particularly volatile sub-regional context, uncertain donor commitment, and years of poor governance. ${ }^{60}$

How did Niger arrive at this conjuncture? A glance at its history, with an emphasis on the history of the southwestern portion of the country, reveals that for several centuries it has remained comparatively isolated from many of the currents that have swept across the African continent, including colonization and globalization.

\section{B. A History of Isolation}

Although the territory that is now Niger was influenced by and occasionally home to pre-colonial city states, principalities and empires, no unified, centralized state existed in this region when the French colonists arrived at the turn of the $19^{\text {th }}$ century. ${ }^{61}$ There was no overarching political leadership, no hereditary leadership class, and, significant for our purposes, no formal courts or unified legal system.

\footnotetext{
${ }^{59}$ See id; see also BUREAU OF AFRICAN AFFAIRS, U.S DEPARTMENT OF STATE, supra note 50. ${ }^{60}$ WORLD BANK, Memorandum of the President of the International Development Association To The Executive Directors on a Country Assistance Strategy of the World Bank for the Republic of Niger, Report No. 25203-NIR, at page i (January 21, 2003); see also Interview with Vincent Turbat, World Bank Representative in Niger, Niamey, Republic of Niger (February 5, 2004) (expressing that view that Niger's only present potential for connecting to the global economy was with vegetable gardening and the exportation of beef).

${ }^{61}$ See Charlick, supra note 48, at 29; Jean Pierre Olivier de Sardan, LES SOCIETES SONGHAY-ZARMA (NIGER-MALI) 20 (1984); Fuglestad, supra note 48, at 34-35.
} 
Though life for Nigerien people changed with colonization, ${ }^{62}$ profound French cultural, social and legal influence was confined mostly to urban areas, ${ }^{63}$ and to an educated class of evolues, or "evolved people," through whom the French ruled. ${ }^{64}$ Because Niger possessed few exploitable natural resources, the French practiced what the economic and social historian Sara Berry refers to as "hegemony on a shoestring." 65 By and large, they were happy to let rural Nigeriens govern themselves as they pleased, so long as they paid taxes, planted the cash crops dictated by France's economic strategy, and supplied sufficient numbers of young men for road construction and other colonial infrastructure projects. $^{66}$

The end result was that the traditions of rural people in Niger, including their legal traditions, survived longer than they would have if, for example, the country had been endowed with diamonds or valuable timber. ${ }^{67}$ This explains, at least in part, why legal traditions such as the gon oracle are vibrant in Niger at the dawn of the $21^{\text {st }}$ century. Many Nigerien legal traditions, including the use of the gon oracle to identify wrongdoers, exist at the intersection of our Western categories of religion and law.

\footnotetext{
${ }^{62}$ See Interview with Village Chief of Gogazi and a group of elders, Gogazi, Republic of Niger (February 19, 2004) (saying that the arrival of the French meant an end to raiding and slavery, and the start of forced labor for the colonial regime); Interview with Bonzoubou Nya and a group of villagers, Fandou Berri, Republic of Niger (May 15, 2000) (recounting stories of the colonial era).

${ }^{63}$ See Kimba Idrissa, La dynamique de la gouvernance: administration, politique et ethnicite au Niger, in LE NIGER: ETAT ET DEMOCRATIE 26-27 (Kimba Idrissa, ed., 2001) (arguing that Niger's pre and post independence states were "minimal," that traditional chiefs were left to govern rural areas, and that there has been an "extraordinary continuity in the resistance to intrusion by the state, both colonial and post colonial").

${ }^{64}$ See Charlick, supra note 48, at 40 (discussing the post-World War II growth of the evolues as a new social group with distinct political and economic interests); Fuglestad, supra note 40, at 120-121, 163.

${ }^{65}$ Sarah Berry, NO CONDITION IS PERMANENT: THE SOCIAL DYNAMICS OF AGRARIAN CHANGE IN SUB-SAHARAN AFRICA 23-24 (1993).

${ }^{66}$ See Charlick, supra note 48, at 35-37.

${ }^{67}$ See Mahomadou Arzika, Droit et Societe au Niger: L’Evolution du Droit Coutoumier 40 (1985) (unpublished Doctoral Thesis, University of Strassbourg)(on file with author) (arguing that traditional social structures remained relatively intact through the brief French colonial period).
} 
While such categories do not exist in the minds of most Nigeriens, our task will be simplified if we continue to rely on them. ${ }^{68}$ We shall take them in turn.

\section{Complex Spiritual Beliefs}

To understand Niger's complex belief system, we will begin with an overview of Niger's pre-Islamic traditions ${ }^{69}$ and then briefly sketch the historical development of Islam in Niger. We will close our discussion with a description of Niger's contemporary blend of traditional and Islamic beliefs.

1. Pre-Islamic spiritual belief

Pre-Islamic Nigerien belief divided the world in to social and spirit domains. ${ }^{70}$

Humans, who inhabit the social domain, are powerless actors in a universe filled with powerful spiritual forces that can and sometimes do destroy individuals and social groups. $^{71}$ The spirits control everything from crop destroying grasshoppers and other vermin to rain, sickness, and longevity. ${ }^{72}$ The actors in the spirit realm include a pantheon of hundreds of individual spirits, some good and some helpful, others evil and vengeful. $^{73}$ If offended, they can wreak havoc in the lives of mortal men and women. ${ }^{74}$

\footnotetext{
${ }^{68}$ See infra, Part IV.A (discussing categorical confusion in legal ethnography).

${ }^{69}$ As with the designations "law" and "religion," here again I have chosen a problematic label for the sake of clarity. I use the phrase "pre-Islamic beliefs," hoping to invoke a category that will seem sensible to my Western audience thereby clarifying this information. However, as discussed below in Part II.C.3, these practices might have developed along side of Islam rather than before it, and Islam might have influenced their development. In short, the term I use oversimplifies a complex reality.

${ }^{70}$ Paul Stoller, FUSION OF THE WORLDS: AN ETHNOGRAPHY OF POSSESSION AMONG THE SONGHAY OF NIGER 14 (1989).

${ }_{71}^{71}$. at 28; see Sidi Chegou, La Preuve des Faits par des Procedes Irrationelles au Niger (unpublished Masters of Law thesis, University of Niamey Faculty of Economic and Jurdic Sciences) (1992), pp. 4 (on file with author) (arguing the spirits intervene regularly in peoples' day to day lives).

${ }^{72}$ Stoller, supra note 70, at xxi, 27; see also Interview with Djibou Mamadou (a practicing zima), Niamey, Republic of Niger (December 15, 2003).

${ }^{73}$ Jean Rouch, LES SONGHAY 62 (1954); see Interview with Djibou Mamadou, supra note 72 (describing different spirit families).

${ }^{74}$ Rouch, supra note 73, at 62.
} 
Communication between the social and spirit realms is possible, and in fact can be necessary for maintaining harmony and health in the social realm. ${ }^{75}$ Typically, mortals who have had some misfortune or evil visited upon them will organize a possession ceremony in which spirits possess the bodies of humans and, communicating through them, explain why they are offended and what the humans can do to atone. ${ }^{76}$

\section{Islam}

Islam was introduced from North Africa to sub-Saharan West Africa in the eighth century along trans-Saharan trade routes. ${ }^{77}$ Although readily adopted by merchants and the ruling class, it did not penetrate into rural areas of Niger until quite recently. ${ }^{78}$

The Islam that eventually took root in Niger is a supple, flexible variety that tolerates divergent traditions and worldviews. ${ }^{79}$ One reason for its flexibility is the Islamic doctrine of ijma, which olds that the consensus of the community of believers is divinely inspired and infallible, ${ }^{80}$ and that the consensus may include customs and traditions of the peoples that Islam has absorbed. ${ }^{81}$ Over time, through application of this doctrine, novel religious rights and beliefs from newly absorbed or conquered people have gained the stamp of orthodoxy, at least regionally. Ijma has thus validated Nigerien

\footnotetext{
${ }^{75}$ Stoller, supra note 70 , at 19, 52.

${ }^{76} \mathrm{Id}$; see Chegou, supra note 71, at 30-33.

${ }^{77}$ G.T. Stride \& Carolina Ifeka, PEOPLES AND EMPIRES OF WEST AFRICA 133 (1971); Nehemia Levitzion, The Early States of the Western Sudan to 1500, in 1 HISTORY OF WEST AFRICA 129-32 (J.F.A. Ajayui \& Michael Crowder eds., 1972).

${ }^{78}$ Arzika, supra note 67, at 236 (arguing Islam did not penetrate into Niger until after the French pacification); Stride \& Ifeka, supra note 77, at 141.

${ }^{79}$ See Ignaz Goldziher, Introduction to ISLAMIC THEOLOGY AND LAW 162 (trans. Andras and Ruth Hamori 1981) 1910 (stating that the Koran warns against branding as unbelievers those whose opinions differ but who belong to those who participate in Islamic prayer services).

${ }^{80} \mathrm{Id}$. at 50.

${ }^{81}$ I.M. Lewis, Introduction to ISLAM IN TROPICAL AFRICA 45 (2 $2^{\text {nd }}$ ed. 1980) (I.M. Lewis, ed. 1964); see id.at 32 (arguing the Islam of Mohammed and of the Koran is unfinished, awaiting its completion in the work of generations to come).
} 
rituals and beliefs that otherwise might have been censured by orthodox Muslims, including the use of oracles to resolve legal matters. ${ }^{82}$

Another explanation of the flexibility of Niger's religion is that most people there follow Islam's Sufi tradition. To a Sufi Mulslim, ${ }^{83}$ the goal of religion is to find and follow the way to personal communion with God, and the strict rules of the Koran are taken merely as points of departure that lead to that lofty path. ${ }^{84}$ Sufi Muslims are particularly tolerant of ancestor veneration and the belief in the mystical powers of spirits, so long as Allah remains preeminent and people do not pray directly to those spirits. $^{85}$

It is also a characteristic of Sufi Islam that a saintly, mystical master must guide the devotee's spiritual quest. ${ }^{86}$ In Niger, and across West Africa, these men, for they invariably are men, are referred to as marabouts. Once a marabout is fully trained and his reputation established, his community relies on him to ward off misfortune and bring good luck, or barka. ${ }^{87}$ Marabouts accomplish this by creating charms ${ }^{88}$ that protect

\footnotetext{
${ }^{82}$ See Goldheizer, supra note 79, at 51; see also Ladislav Holy, RELIGION AND CUSTOM IN A MUSLIM SOCIETY, THE BERTI OF SUDAN 10 (1991); Loic Garcon, Etude de l'Evolution des Pratiques de l'Islam au Niger (Study and report commissioned by Office of the Embassy of Canada in Niger, July, 1998), at 26 (notes on file with author) (arguing that Islamic law in Niger is comprised largely of traditions absorbed into Islam).

${ }^{83}$ The word Suffi derives from the Arabic suf, or wool, that described the hair shirts donned by the selfabnegating believers. Annemarie Schimmel, MYSTICAL DIMENSIONS OF ISLAM 14 (1975).

${ }^{84}$ See Goldziher, supra note 79, at 138-150 (arguing Sufi Muslims believe that beneath the literal sense of the sacred texts lie profound philosophical truths, which allegorical interpretations can bring to light).

${ }^{85}$ Lewis, supra note 81 , at 62.

${ }^{86}$ Charlotte A. Quinn \& Frederick Quinn, PRIDE, FAITH AND FEAR, ISLAM IN SUB-SAHARAN AFRICA 14, 92 (2003).

${ }^{87}$ See Jean Rouch, LA RELIGION ET LA MAGIE SONGHAY 289 (2d. ed. 1989) (1960); David OwusuAnsah, Prayer, Amulets, and Healing, in HISTORY OF ISLAM IN AFRICA 478, supra note 11.

${ }^{88}$ Vincent Monteil, Marabouts, in ISLAM IN AFRICA 94 (James Kritzeck \& William H. Lewis, eds. 1969). Although we use the word "charm" or "amulet" or "talisman," Zarmas use the word safari, which translates to "treatment" or "cure" and also is used to mean "medicine." They use the same word for traditional remedies as for antibiotics or aspirin obtained from pharmacies. In other words, their vocabulary does not distinguish between spiritual and pharmaceutical medicine.
} 
travelers from harm, ${ }^{89}$ cure outbreaks of measles, ${ }^{90}$ compel love and devotion from reluctant members of the opposite sex, ${ }^{91}$ and serve countless other protective and preventative functions. $^{92}$ As we shall discuss at some length in Part IV, below, Nigerien Sufi Muslims also rely on marabouts to dispense what we would consider "law" by identifying thieves and other wrongdoers. ${ }^{93}$

\section{Today's religious mixed bag}

Today, the vast majority of Niger's people professes Islam and follows the Five

Pillars, ${ }^{94}$ yet as a result of the processes of adaptation and evolution described above, their Islamic practice includes many elements that orthodox Middle Eastern Muslims find foreign, even heretical. ${ }^{95}$ This includes, for example, the belief that a person can obtain

\footnotetext{
${ }^{89}$ Before leaving Niger, friends from the village of Fandou Berri commissioned a marabout to make charms for my three children to protect them on their journey back to the United States. They consist of selected verses from the Koran written on paper, folded, encased in protective leather pouches, then attached to string to be worn around the neck.

${ }^{90}$ During my recent stay in Niger I was alarmed one day to learn from a friend that there had been a measles outbreak in his village and that a child had died. He assured me that the villagers had obtained safari, or medicine, that the outbreak had been contained, and that his children were no longer in danger. Later, when I visited the village and observed that all of the young children were laden with leather pouches, I inquired and learned that the "medicine" my friend had referred to was the charms that had been created by a powerful local marabout. See Interview with Bachirou Djibo, Fandou Berri, Republic of Niger (February 4, 2004).

${ }^{91}$ See Holy, supra note 82, at 32 (explaining that marabouts order the drinking of ink to induce the affection of a woman).

${ }^{92}$ See generally Owusu-Ansah, supra note 87, at 479; see also Holy, supra note 82, at 25, 27-33 (explaining that the Koran is believed to have immense power to guarantee the wellbeing of those who internalize it, and that the literate achieve this result by memorizing it while the illiterate achieve the same effect by wearing Koranic verses as amulets or by drinking ink that has been used in writing Koranic verses); Interview with Oumarou Alzuma, Niamey, Republic of Niger (April 14, 2004) (stating that his work as a marabout includes healing the sick and writing verses that will help his clients intercede with God and get the result they're seeking).

${ }^{93}$ See generally Holy, supra note 82, at 34 .

${ }^{94}$ See id. at 1 (naming the five pillars as: bear witness to the oneness of God, perform five daily prayers, fast during Ramadan, pay annual alms, and carry out the pilgrimage to Mecca at least once).

${ }^{95}$ Scholars disagree on the historical mechanism by which Niger, and more generally West Africa, developed its heterodox, magic-infused brand of Islam. Some speak of the "survival" of pre-Islamic practices. Their assumption is that people living in West African communities where Islam was being introduced maintained their pre-Islamic beliefs and practices by simply layering a thin veneer of Islamic ritual onto their traditions and then calling them Muslim. Other scholars speak of "great" and "little" traditions in Islam, the great being more orthodox beliefs and practices that emanate from the Middle East (where Islam was born) and "little" being the folk ways that have been incorporated into Islam as it has spread. Still others criticize the "survival" thesis and "great versus little" dichotomy as overly simplistic.
} 
Islamic charms that will make any knife turned against him melt before it penetrates his flesh. ${ }^{96}$ It also means that people believe that they can and should rely on nominally Islamic oracles like the gon to resolve certain kinds of legal disputes.

\section{Law in Niger}

We begin with an overview of the state legal system in Niger, then turn to a discussion of how most Nigeriens actually understand law.

\section{State law in Niger}

Immediately following independence from France in 1960, Niger adopted the French Civil Code as its own state law, with a general exception for those laws that conflicted with Niger's new constitution. ${ }^{97}$ The exception clause gave rise to enduring confusion, since no one bothered to point out which laws might conflict. ${ }^{98}$ In the end it hardly mattered because Niger spent most of the following decades under military rule, and state law became whatever the soldiers said it was. ${ }^{99}$ Since the fall of the Berlin Wall and the end of the Cold War, Niger has been lurching unevenly toward democratic rule. ${ }^{100}$ It is only since 1999 , the beginning of Niger's present sustained period of

They note that the Koran recognizes mystical forces and spirits, and that Islam itself may have imported mystical practices to parts of Africa where they either did not exist before Islam or existed in other forms. These scholars view the relationship between Islam and non-Islamic belief systems as a fluid, ongoing exchange. For a discussion of these points, see Holy, supra note 82, at 42 and 139, and I. M. Lewis, RELIGION IN CONTEXT: CULTS AND CHARISMA 139-142, 152 (2 $2^{\text {nd }}$ ed. 1996) 1986.

${ }^{96} \mathrm{I}$ base this statement on an unrecorded conversation with Bachirou Djibo that took place during the early spring of 2004. Devout Nigerien Muslims also consistently acknowledge the presence and importance of their ancestors' spirits. To give one example, a friend living in a rural Zarma village built a new grass hut for himself and his family, taking advantage of a prime spot of real estate that had been vacated when his paternal grandmother died. When I asked why he did not build the new hut on the sand foundation of the old one, he responded matter-of-factly that he did not want to risk harm to his family by offending his grandmother's spirit. Interview with Gibirou Djibo, Fandou Berri, Republic of Niger (May 6, 2004).

${ }_{97}$ Christian Lund, Struggles for Land and Political Power: On the Politicization of Land Tenure and Disputes in Niger, 40 J. LEGAL PLURALISM \& UNOFFICIAL L. 8 (1998).

${ }^{98} I d$. at 9.

${ }^{99}$ See Mission d'Analyse, supra note 22, at 6.

${ }^{100}$ See id. at 5-6. For a summary account of Niger's post-Independence political and economic history, see BUREAU OF AFRICAN AFFAIRS, U.S DEPARTMENT OF STATE, BACKGROUND NOTE: NIGER, supra note 50 . 
democracy and relative stability, that the country's leaders, encouraged by donor nations and international financial institutions, ${ }^{101}$ began taking a close look at its legal system with an eye toward making it coherent, rational, and modern. ${ }^{102}$

From the government's perspective, and from the perspective of legal experts from Western donor countries, Niger's law is based upon a Constitution, adopted in 1999, that enshrines principles familiar to the West. ${ }^{103}$ For example, it embraces the separation of powers (article 28), the separation of church and state (article 4), a society based on the rule of law (article 99), an independent judiciary (articles 100 and 101), and a respect for internationally defined human rights (articles 10-34). ${ }^{104}$

Niger's court system also follows a familiar pattern. There is a Supreme Court, based in the capital, Niamey, two courts of appeal, one in Niamey and one in Niger's second city, Zinder, six regional tribunals distributed throughout the country, and twentyfive judicial delegations that deal with smaller cases. ${ }^{105}$

Beginning at independence and continuing through Niger's recent law reforms, ${ }^{106}$ Niger's state legal system has embraced and legitimated certain aspect of what it refers to as droit coutumier, or "customary law." ${ }^{107}$ Specifically, in matters concerning marriage, divorce, filiation, succession, gifts, testaments, and in certain matters concerning

${ }^{101}$ See supra Part II.

${ }_{102}^{102}$ See generally Mission d'Analyse, supra note 12.

${ }^{103}$ See REPUBLIQUE DU NIGER, LA CONSTITUTION (1999) [hereinafter, Niger Constitution].

${ }^{104} I d$.

${ }^{105}$ See Mission d'Analyse supra note 12, at 7-11.

${ }^{106}$ See infra Part IV.

${ }^{107}$ Niger's legitimization of customary law is in contrast to most post-colonial African nations, which tried to create uniform state legal systems by suppressing multifarious legal traditions at the time of independence. See Amadou Tankoano, Les Sources du Droit au Niger, in MODE DE PRODUCTION DES DROITS AFRICAINS ET COMMON LAW 133 (1995). Some commentators distinguish the term "customary law" and "traditional law," the former referring to the colonially invented law that state courts and other organs of the state apply, the latter referring to the law that is applied by traditional political and religious leaders completely apart from contact with any state organ. See Abdourahaman Chaibou, Le Transfert Des Concepts du Droit Processuel Francais au Niger (June 1997) (unpublished doctoral dissertation, University of Orleans), at p. 22. (on file with author). 
commercial contracts and real property, judges may apply customary law to resolve disputes. ${ }^{108}$ Significantly for our purposes, the state does not permit the application of customary law in criminal matters. ${ }^{109}$

On paper, and from our Western perspective, Niger's legal system appears quite orderly and rational: it enshrines principles of individual and human rights, borrows the structure of Western legal systems, and honors non-Western legal traditions by carving out a limited domain for the application of "customary law." If this is how Niger's contemporary legal system works, one might ask, what could be wrong with the current reforms, the goal of which is to update and modernize that system? But that would assume that Niger's contemporary law is actually that which is described in its written legal texts. As the discussion below reveals, that is far from the case.

\section{The dominance of non-state law in Niger}

In fact, Niger's legal system looks completely different from the perspective of most of its citizens. To them, the rational and orderly system described above is

\footnotetext{
${ }^{108}$ See Article 51 of the Law 62-11 of 16 march 1962, concerning the organization and competence of the jurisdictions of the Republic of Niger; see also Tankoano, supra note 107, at 133. The law requires judges to set aside custom and instead apply state civil law if the custom is contrary to public order and the liberty of persons. The court must also disregard custom where both parties request it, or where one party cannot take advantage of custom or has totally or partially renounced custom as an unequivocal act of will. See Abdourahaman Chaibou, L'Influence de la Jurisprudence " Nigerienne en Droit de la Famille Sur la Coutume: Les Notions "D'Evolution Generale du Pays" et de "Coutume Urbaine » REVUE NIGERIENNE DE DROIT 71 (No. 02, December 1999).

${ }^{109}$ See Article 78 of law 62-11 of 16 March 1962. Traditional chiefs also play an important role in the law, politics, and culture of contemporary Niger. Unfortunately, all but a glancing treatment is beyond the scope of this paper. For a dated but still relevant English language discussion of that topic, see Pearl Theodora Robinson, African Traditional Rulers and the Modern State: The Linkage Role of Chiefs in the Republic of Niger (1975) (unpublished doctoral dissertation, Columbia University) (notes on file with author). The chiefs' participation in the law of contemporary Niger is confusing because they play two very distinct roles. At times, they act as quasi-state administrators who are specifically empowered to conciliate in certain disputes; at other times acting as traditional leaders - completely unconnected to the state or its formal system of laws - to resolve disputes and achieve justice. See Abdourahaman Chaibou, Les Juges, le Cadis, le Chef et les Autres ..., REVUE JURIDIQUE DU SAMAN (SYNDICAT AUTONOME DES MAGISTRATES DU NIGER) 5 (No. 001, July-August 1998); Abdourahaman Chaibou, Le Role des Juges Traditionnels Dans le Processus de Reglement des Conflits au Niger, in LE JUGE: UNE FIGURE D'AUTHORITE 138 (1996); Idrissa, supra note 63, at 24.
} 
unknown and unknowable, and they come into contact with it rarely and only when absolutely necessary. ${ }^{110}$

For most Nigeriens, particularly rural people, an obvious problem with the law of the state is that it is written in French, which an overwhelming majority does not understand. $^{111}$ Even for francophone Nigeriens, the French culture of Niger's state legal system presents insuperable barriers: lawyers, judges, and court personnel, many of whom are educated in France, dash about wearing long black robes and ceremonial ruffled collars, communicating to one another in technical legal terms, leaving the average Nigerien petitioner completely mystified. ${ }^{112}$

Furthermore, Niger's people view the state legal system as irreparably corrupt. ${ }^{113}$ Those citizens who know anything at all about the state system know that one cannot get justice from it if one does not have money to offer the judge. ${ }^{114}$

Even those rare citizens who desire contact with the state's legal system have great difficulty because it is fatally under-resourced. In 2002, there were 140 judges in the country, which translated at that time to approximately one judge for every 80,000

\footnotetext{
${ }^{110}$ Kelley, supra note 12, at 659 (arguing that rural Nigeriens rarely know or care about the content of state law); Tankoano, supra note 107, at 135, 137; Chaibou, L'Influence de la Jurisprudence, supra note 108, at 71; Chegou, supra note 71, at 2; see Idrissa, supra note 63, at 26-27 (arguing Nigeriens today identify much more closely with their traditional rulers than with the Nigerien nation-state).

${ }^{111}$ Mission d'Analyse, supra note 12, at 24; see supra notes 55, 56 and accompanying text.

${ }^{112}$ See Mahaman Tidjani Alou, La Petite Corruption au Niger, Etudes et Travaux No.3, (report published by Laboratoire d'Etudes et Recherches sur les Dynamiques Socials et le Development Local, January 2002) at p. 70 [check page \#] (copy on file with the author); see also Garcon, supra note 82, at 28 (arguing most Nigeriens do not understand the functioning of the justice system).

${ }^{113}$ See Alou, supra note 112, at 23-35; Mahaman Tidjani Alou, La Justice au Plus Offrant, Les Infortune de Systeme Judiciaire en Afrique de L'Ouest (Autour de Cas de Niger), in POLOTIQUE AFRICAINE, LA CORRUPTION AU QUOTIDIEN 61 (Editions Karthala 22-24, No. 83, October, 2001); Alhada, supra note 6, at 80; Mission d'Analyse, supra note 12, at 13 (stating corruption exists throughout Niger's judiciary).

${ }^{114}$ Alou, supra note 113, at 64-66. Influence peddling is another frequent form of corruption. Although the independence of state judges is guaranteed by Articles 98 and 100 Niger's Constitution, parties to legal proceedings often prevail by seeking intervention by politicians from the executive branch of government. The politicians phone the judges with instructions, and if the judges fail to obey, they find themselves assigned to backwater posts and stuck in the lower rungs of the civil service. See Alou, supra note 113, at 66; Mission d'Analyse, supra note 12, at 11.
} 
inhabitants. ${ }^{115}$ Lawyers are even harder to find. In 2003, there were 77 lawyers ${ }^{116}$

practicing in the entire country, and none of them maintained an office outside of

Niamey. ${ }^{117}$ The courthouses and other government facilities where citizens might find a portal into the state legal system are widely disbursed and, with travel on public transportation beyond the means of most Nigeriens, virtually impossible to reach. ${ }^{118}$ The rare citizen who does find his or her way to a courthouse, encounters the most Spartan of conditions. Most have no library, computers or even basic amenities such as telephone lines or usable office furniture. ${ }^{119}$

Even if Nigeriens could overcome all of these barriers and shortcomings, the substance of the laws applied in the state courthouse would make little sense to them. The traditional, non-state law that most Nigeriens rely upon is premised on a culturally distinct notion of justice. In the next section we will discuss specific examples of that traditional law - in particular the use of the gon oracle to identify wrongdoers and resolve disputes - but in preparation for that discussion we can run through a thumbnail sketch of traditional law.

First, traditional law in Niger is based on process, not rules. Parties negotiate over just outcomes to their disputes. There are flexible norms concerning who should participate in the negotiation, but in general it can be said that elders, traditional chiefs,

\footnotetext{
${ }^{115}$ Mission d'Analyse, supra note 12, at 11 (adding that the World Bank norm is one judge for every 20,000 inhabitants.)

${ }^{116}$ More precisely, there were 77 avocat, which in the French legal system is the rough equivalent of an American lawyer.

${ }^{117}$ Mission d'Analyse, supra note 12, at 14; see also M. Aksar, Rentree Solonnele du Barreau de Niamey: Pour une Presence Plus Marquee des Avocats Dans la Vie de la Cite, L'EVENEMENT, March 1, 2005, at p. 5 (commenting on Niger's scarcity of lawyers).

${ }^{118}$ See Garcon, supra note 82, at 28 (arguing many Nigeriens cannot afford to travel to cities to bring legal matters before judges); see also Alou, supra note 112, at 24.

${ }^{119}$ See Mission d'Analyse, supra note 12, at 12-13; see also Interview with Judge Hasimiou, Niamey, Republic of Niger (December 16, 2003) (noting a lack of computers even in Niamey courthouses).
} 
and respected spiritual leaders act as facilitators and guide the parties toward a just outcomes.

In guiding the parties, the community leaders draw upon no fixed body of rules or precedent, and rarely if ever bring state law or Islamic sharia law into the discussion. Significantly, the leaders' goal in these discussions is not to punish a wrongdoer, exact vengeance, or even protect the rights of the party who claims to have been injured. Rather, those leaders seek an outcome that will restore equilibrium to the social unit. Often, the process of restoring equilibrium to the village or extended family involves asking the perceived wrongdoer to compensate the victim for his loss, but as often as not, history will be invoked, and a victim's request for compensation will be met with a reminder that his ancestor owed some debt of gratitude to the family of the wrongdoer, and that the victim can pay that debt by forbearing in this particular instance. Where the parties agree that immediate compensation is warranted, the victim generally is content to receive compensation from the wrongdoer's family rather than from the wrongdoer himself because, once again, the point of the process is to restore the community, not punish the wrongdoer.

Very much unlike the law of the West, Nigerien tradition makes no categorical distinction between public law and private law, nor does it conceptually separate criminal law from civil law. Law is a process for establishing a modus vivendi for a community, and is inextricably interwoven with family relations, community relations, history, and spiritual beliefs. ${ }^{120}$

\footnotetext{
${ }^{120}$ Colleagues who are legal historians have pointed out that this description of traditional law in Niger, and indeed, of Niger's present state of tension between traditional and state law, echoes a period during the $12^{\text {th }}$ century in Europe when Roman law was being revived and applied at the expense of more traditional and
} 


\section{E. Summary}

Niger is an extremely poor, isolated country with dim prospects for significant economic development. Due at least in part to its poverty and isolation, Niger's traditional beliefs and practices have remained comparatively vibrant into the $21^{\text {st }}$ century. According to those beliefs, law is not a separate socio-cultural category, but is instead bound up with history and community relations and, in particular, with spiritual beliefs.

Niger's spiritual beliefs are a complex mixture of traditional spirit worship and Islam. The country's very tolerant brand of Islam permits unorthodox practices, including peoples' reliance on mystical oracles to resolve disputes.

Niger's law looks completely different from the perspective of the state than from the perspective of most of its citizens. To them, law is an open and flexible process for restoring harmony to their families and communities and is not a tool for enforcing individual rights or punishing individual wrongdoers.

Below, we will discuss specific examples of the law as it is understood and practiced by most Nigeriens.

\section{The Use of the Gon Oracle in Niger}

The gon, first glimpsed in Part I.B., above, is only one example of traditional law employed by Nigeriens; in fact, it is only one of many oracles that Nigeriens rely upon. ${ }^{121}$

localized Germanic law. See generally John Henry Merryman, THE CIVIL LAW TRADITION 6-13 (2 ${ }^{\text {nd }}$ ed. 1985). Fascinating as this parallel may be, I must leave it as a topic for future exploration.

${ }^{121}$ While the gon is considered Islamic, some Nigeriens rely on non-Islamic oracles to help resolve legal disputes. The tarkama oracle, for example, is led by a traditional priest called the Magagin Duma who presides over a ceremony in which a goat is slaughtered and placed on a litter. Four litter bearers hoist the goat carcass, which then leads them to the wrongdoer. See Chegou, supra note 71, at 9-11. A similar oracle, the tunguma, relies on a magic stone to lead its bearers to the guilty party. Chegou, supra note 71 , at 11 to 24. Interestingly, ancient Egyptian oracles used a similar method, placing a figure of a deity on a litter that then would physically lead the litter bearers to the wrongdoer. See Russ VerSteeg, The 
We focus on it as emblematic of traditional Nigerien law for three reasons. First, its use is widespread. Second, it happened to be what Nigerines talked about when, years ago, I began posing general questions about theft and dispute resolution to ordinary, non-elite citizens. Third, it furnishes a convenient contrast with Western law because the Washington Legal Consensus has made reform of the country's Criminal Codes a priority, and at present the gon is what people are relying upon to cover the same ground. We begin our exploration of the gon with a brief discussion of how one goes about researching it.

\section{A. Methodology of studying the gon.}

Traditional law in Niger is not written, so one cannot hope to learn about it without venturing into the field to observe and ask about it. My exploration of Niger's legal traditions, particularly the gon, has relied on a mix of interviews and observation that took place during a year of fieldwork in Niger in 2003-2004 and during two monthlong visits in 2000 and 1996.

In rural areas, most of the interviews I conducted were semi-structured group interviews, an unavoidable form of information gathering in small villages where adult men of noble birth feel entitled to insert themselves into all but the most intimate of conversations. In the big city, Niamey, I was able to perform some one-on-one interviews and, on three occasions, witness the gon in action. ${ }^{122}$

\footnotetext{
Machinery of Law in Pharaonic Egypt: Organization, Courts and Judges on the Ancient Nile, 9 Cardozo J. Int'l \& Comp. L. 129 (Spring, 2001). There also are reports of oracles in Niger that involve sticking needles into chunks of soap, see Interview with Oumarou Alzuma, supra note 92, staring into water, drawing figures in the sand and scattering cowry shells, see Chegou, supra note 71, at 34, and administering poison to the suspected wrongdoer, see Arzika, supra note 67, at 129.

${ }^{122}$ For unknown reasons - perhaps because the novelty of my presence wore off or because I was reluctant to pay for the privilege - I was not invited to witness any gons after the initial three. Though I spent much of my time in rural areas, I have never witnessed a rural gon for the simple reason that thefts and other
} 
Nigeriens speak various languages, and grappling with them added a certain amount of extra work and imprecision to my study of the gon. ${ }^{123}$ But linguistic complications are merely the skin of a more profound methodological challenge: categorical confusion. Any attempt to understand and describe another culture risks skimming over the fact that different cultures categorize and understand the world differently. A simple but important example of this categorical dissonance is my use of the word "law" throughout this paper. As alluded to in our discussion of spiritual beliefs in Part III.B, above, Nigeriens, particularly rural Nigeriens, do not conceive of a separate socio-cultural category called "law" the way we in the West do. For them, there is no conceptual division between "law" and the rest of their social and spiritual lives. In fact, the Zarma language contains no word for "law."124 Thus, when I use the terms "law" and "legal" in the parts of this paper that discuss Western law, I am using culturally appropriate descriptors, but when I use those words in discussions of traditional Nigerien "law," I am in a sense cheating: falling back upon convenient, shorthand descriptions that our language and worldview include but theirs do not. ${ }^{125}$

wrongs occur infrequently in small villages and, when they do, usually are resolved by means of mediation and negotiation.

${ }^{123}$ Most of the interviews were in Zarma, a language I speak and understand reasonably well. Some interviews, particularly in the capital city, were in Hausa, of which I know nothing. In all the interviews, I was aided by a collaborator, Bachir Tidiani, who is fluent in Zarma, Hausa, and French.

${ }^{124}$ When referring to that Western category, Zarmas usually fall back on French terms such as droit and justice. When I explain to rural Nigeriens our "law" category, the closest word they can produce in their language is chimi, which means simply "truth."

${ }_{125}$ Another example is my use of the English word oracle to describe the gon and similar religio-magic rites that Nigerien people rely upon to identify wrongdoers. According to WEBSTER'S THIRD NEW INTERNATIONAL DICTIONARY (1993), oracle means 1(a)(2) "a typically ambiguous or enigmatic revelation or utterance believed to issue from a divinity through a medium (as a priest or priestess) thought to be inspired ...2(a)(1) a medium by which a pagan god reveals hidden knowledge or makes known the divine purpose." They do not use any similar categorical word, and instead refer to a given rite or ceremony by its proper name, in this case, gon. When we use the word oracle in English, it conjures visions of ancient, Roman priestesses in white flowing robes communicating with Olympian gods. Nigeriens, on the other hand, have no cultural history that explicitly or implicitly associates the gon or other rites with an ancient, revered civilization. 
Where mystical phenomena are involved, the potential for categorical confusion is greater still. This is because oracles, magic and the occult, all of which are employed in traditional law, occupy fundamentally different positions in Western versus African worldviews. To Westerners, these subjects are exotic and supernatural; they are the stuff of fireside ghost stories that send tingles up listeners' spines. ${ }^{126}$ But to most Nigeriens, such phenomena are mundane. ${ }^{127}$ The Zarma language does not include a word for "supernatural,", 128 because to them, magical and mystical phenomena are perfectly natural. ${ }^{129}$ The only mystery concerns how and when actors in that realm will intrude upon and affect, positively or negatively, the lives of mortals. ${ }^{130}$

The reality of such categorical dissonance can lead to a fascinating debate about whether it is legitimate, or indeed possible, for an outsider to presume to understand and describe the culture, or for that matter the law, of an "other." I intend to sidestep that debate. ${ }^{131}$ In this paper, I have attempted and will attempt to minimize categorical

\footnotetext{
${ }^{126}$ The Western Press delights in reporting the mystical beliefs of Africans. See e.g., Sharon LaFraniere, $A$ Ghost Story Turns Very Scary for Malawi Journalists, N.Y. TIMES, March 29, 2005, at A4 (reporting Malawians' belief that their president had fled from his palace because it was haunted by spirits); Denise Grady, Deadly Virus Alters Angola's Traditions, N.Y. TIMES, April 19, 2005, at _(noting that funerals must be conducted according to tradition to avoid neglecting spirits who might turn vengeful); Michael Wines, Rain Queen is Dead, but Debate Over Her Power Lives On, N.Y. TIMES, June 21, 2005, at A2 (discussing the death of a South African queen whose family is widely believed to have the power to produce rainfall).

${ }^{127}$ John Comaroff \& Jean Comaroff, Policing Culture, Cultural Policing: Law and Social Order in Postcolonial South Africa, 29 LAW AND SOCIAL INQUIRY 513, 524 (Summer, 2004); E.E. EvansPritchard, WITCHCRAFT, ORACLES AND MAGIC AMONG THE AZANDE 64-68, 80-83 (1968).

${ }^{128}$ Jean-Pierre Olvier de Sardan, Occultism and the Ethnographic 'I': the Exoticizing of Magic from Durkheim to 'Postmodern Anthropology,' CRITIQUE OF ANTHROPOLOGY 11, 13 (SAGE London, Vol. 13(1): 5-25). Zarma's refer to the spirit world as ganji or "bush," which hints at their conception of that realm. Designating it as "bush" assigns it a temporal and spiritual location outside the structured life of the village but still very much connected to it. The village, $k w a r a$, is where relations and social outcomes are subject to human control and agency. The bush, which begins just beyond the village's fields, is a place where life is not ordered and mortals enjoy no domain, especially after dark.

${ }^{129} \mathrm{Id}$. at 11 .

${ }^{130}$ See id.

${ }^{131}$ For a sample of works that engages this topic and recounts the evolution of post-modern anthropology, see WRITING CULTURE: THE POETICS AND POLITICS OF ETHNOGRAPHY (James Clifford \& George E. Marcus eds., 1986); George E. Marcus and Michael M. J. Fisher, ANTHROPOLOGY AS A
} 
confusion by pointing out differences between Nigerien and Western cultural categories, and by flagging for the reader the instances where I am sacrificing cultural accuracy for the sake of ease and conceptual clarity. ${ }^{132}$ Before leaving behind this discussion of categorical dissonance, it is worth noting that Washington Legal Consensus reformers evince no understanding of the possibility that the "law" they seek to impose is not a familiar or appropriate category for the societies upon which they are acting.

\section{B. The gon}

During my recent year of fieldwork in Niger, I collected accounts of sixteen gon oracles, eleven of which took place in the Zongo neighborhood of Niamey. ${ }^{133}$ The first gon I observed was described in Part I.B, above. Below, I will provide descriptions of another Zongo gon I witnessed, and, in the course of analyzing those gons, refer to illustrative cases from among the many secondhand accounts I have collected.

The origin of the gon is obscure. ${ }^{134}$ Unlettered rural people generally insist that the entire procedure for the gon is laid out in detail in the Koran. This is not the case.

CULTURAL CRITIQUE: AN EXPERIMENTAL MOMENT IN THE HUMAN SCIENCES (1986). For a readable and entertaining rendition of the same, see Clifford Geertz, WORKS AND LIVES: THE ANTHROPOLOGIST AS AUTHOR (1988), particularly that collection's final essay, Being Here: Whose Life is it Anyway?, at pages 129-149.

${ }^{132}$ Others have pointed out challenges faced by Western researchers who attempt to describe mystical phenomena. The venerable E. E. Evans Pritchard, when writing about witchcraft and oracles among the Zande people of the Sudan, noted that the researcher feels the need to supply his Western readers with an account of the mystical phenomenon that is orderly and rational when that which is observed often is neither and when, to most Westerners, the very notion of using magic or consulting oracles is the quintessence of irrationality. See Evans-Pritchard, supra note 16, at 82; see also Peter Winch, Understanding Primitive Society in PERSPECTIVES ON AFRICA, A READER IN CULTURE, HISTORY, AND REPRESENTATION, supra note 1, at 312; Jean Rouch, LA RELIGION ET LA MAGIE SONGHAY 39 (2d. ed. 1989) (1960).

${ }^{133}$ My emphasis in this paper on gon oracles that took place in Niamey's Zongo neighborhood provides what is perhaps a skewed sampling because the urban Zongo gon has regular interaction with the state police and court system while rural gon practitioners and parties rely almost exclusively on the oracle to identify wrongdoers and rarely have any contact with the state system. In spite of this paper's emphasis on the Zongo gon, a majority of gon accounts I have recorded took place in rural villages. I reported a few of these at Kelley, supra note 12, at 673-680.

${ }^{134}$ See infra note 95 for a discussion of whether oracles and other mystical phenomena in contemporary West Africa can justly be described as pre-Islamic. My primary interest is in the role that the gon plays in 
One Nigerien scholar of Arabic language and Islam told me that he is quite sure that the gon was adapted from pre-Islamic practice and that the ritual incantations that once accompanied it were simply replaced by the reading of Koranic verses. ${ }^{135}$ This may be true, but that scholar could point to no particular reason for assuming it to be so and knew of no research that had been performed on the subject. ${ }^{136}$ A learned marabout from the holy city of Say in Niger dismissed the gon entirely, saying it was merely a children's game that had caught on among naïve people in Niger. ${ }^{137}$ We thus can only speculate about the origins of the gon, but can say with certainty that today it is practiced widely, at least throughout southwestern Niger, ${ }^{138}$ and that the gon of the Zongo neighborhood in Niamey is widely considered to be the "standard."139

The Zongo neighborhood was founded and populated long ago by piously Islamic Hausa traders. In the 1960s, Malam Hassan, a resident of Zongo, was the most important Islamic leader in Niamey. He maintained a Koranic school that drew students from

contemporary Nigerien legal culture and law, and so I prefer to avoid any debate about whether it is, as some maintain, an animist "holdover" sporting a thin veneer of Islam.

${ }^{135}$ Interview with Dr. Moulaye Hassane, Niamey, Republic of Niger (November 19, 2003); Interview with Dr. Moulaye Hassane, Niamey, Republic of Niger (February 16, 2004). During an interview with the Sarkin of Zongo he once mentioned that the gon was based on a pre-Islamic, animist practice called dongo. I pressed him for more details, but when he saw my enthusiasm for this line of questioning, he impatiently declined to give further information. Although I asked others about the significance of dongo, I received no further information. See Interview with Hamza Maman Bako, supra note 11.

${ }^{136}$ See Interview with Dr. Moulaye Hassane (November 19, 2003), supra note 135.

${ }^{137}$ Interview with the President of the Islamic Association and the Cadis of Say, Say, Republic of Niger (February 25, 2004).

${ }^{138} \mathrm{My}$ fieldwork has focused on this region. While it is clear that the gon is widespread in this zone, I am less certain that it is widely practiced in other parts of Niger. I have heard accounts of the gon being performed in other regions of Niger and in other countries in West Africa, but people from southwestern Niger were always involved, leaving it unclear whether the gon was indigenous to those other areas. See, for example, Interview with village chief and a group of elders, Saabu Dey, Republic of Niger (December 18,2003 )(recounting a gon that took place among Zarma men who were living temporarily in Mali). I also have seen a reference to the gon being performed in Diffa, which is near Niger's eastern boarder, more than a thousand kilometers distant from Zongo. Chaibou, supra note 107, at 446. One last bit of evidence arguing for the widespread use of the gon is that the Sarkin of Zongo claims that it is of Hausa origin, which would place it in central and eastern Niger. See Interview with Hamza Maman Bako, supra note 11. ${ }^{139}$ See Interview with Oumarou Alzuma, supra note 92; Interview with Hamza Maman Bako, supra note 11; see generally Chegou, supra note 71, at 57-62; Chaibou, Le Role Des Juges Traditionnels, supra note 109 , at 145 . 
around the region. In 1964, he suggested to the grandfather of the present Sarkin of Zongo that they should begin reading the gon there. ${ }^{140}$ The Zongo gon's reputation for accuracy spread rapidly, and soon people were traveling from far and wide to consult it. Taking advantage of the Zongo gon's perceived infallibility, Niamey law enforcement officials regularly sent parties to Zongo to determine culpability and resolve disputes. ${ }^{141}$

Two principal actors animate the Zongo gon: the Sarkin of Zongo and the Zongo marabout. The present Sarkin was born in 1954 and was chosen by acclamation to lead the community when his father died in $1993 .{ }^{142}$ Today he acts as the traditional chief for the Zongo neighborhood, convening elders to decide neighborhood policy, organizing communal labor projects, helping conciliate when families or individuals fall into conflict, and collecting taxes that he sends on to Niger's central government. In addition to his other duties, it is his traditional obligation to preside over the gon oracle.

When parties approach the Sarkin with a request to submit their dispute or question to the gon he must decide whether the request is appropriate. Occasionally, he refuses to perform the gon, when, for example, the identity of the transgressor is already certain based on the circumstances. He says that the power of the gon is too great and the physical danger to the marabout is too extreme to perform the gon when it is not truly needed. When he determines that the gon is appropriate, he presides over the preliminary

\footnotetext{
${ }^{140}$ Although the Sarkin did not state it directly, he implied that the gon was known to exist elsewhere before it became common practice in the Zongo neighborhood in 1964.

${ }^{141}$ See infra note 160.

142 The Sarkin's family history is based upon Interview with Hamza Maman Bako, supra note 11. Before becoming Sarkin, Hamza worked as a bank's accountant in a now largely abandoned skyscraper that towers over the northwestern end of the Zongo neighborhood.
} 
gathering of facts, guides all parties through the various oaths they must utter, and, ultimately, poses precisely framed questions to the oracle. ${ }^{143}$

The second principle actor in the Zongo gon is the current head marabout of the neighborhood mosque, Oumarou Alzuma. ${ }^{144}$ He is in his fifties, but he does not know his exact age. At thirteen, he left his natal village and began his religious studies under a highly respected marabout who was distantly related to his family. After six years of rigorous Koranic study, he moved to the holy city of Say and spent several more years under the tutelage of important Islamic religious leaders. Around the year 1970, he sought and was granted the position of acolyte to Malam Hamisou, a marabout of great reputation who was based in Zongo. Over the years he became the Malam's trusted colleague and confidant, eventually moving into the great man's home. Along with other junior marabouts, Oumarou led prayers in the Zongo mosque, created Islamic charms and incantations that warded off ill fortune and healed the sick, and, on behalf of pious petitioners, sought God's favor for advantageous business relations, safe travel, or strength against enemies.

In approximately 2001, the master of the Zongo gon died, and the Malam initiated Oumarou into its power and its secrets. Oumarou will not discuss the secrets he learned or exactly what sort initiation he experienced, but he will share the fact that the gon is both powerful and dangerous, and that he must be strong and of pure mind and body to avoid being harmed by it.

\footnotetext{
${ }^{143}$ When the Sarkin is called away from the neighborhood, usually to take care of administrative business arising from his government sanctioned position as chef de quartier, or neighborhood chief, his younger brother, Boubacar, stands in and presides over the gon.

${ }^{144}$ Unless otherwise noted, all of the information in the following paragraphs regarding the Zongo marabout comes from Interview with Oumarou Alzuma, supra note 92.
} 
Today, it is rare that more than a day goes by without a request for a gon. The majority of cases involve theft, but people sometimes consult the gon for other reasons. For example, not long ago there was a man who had two wives. He caught a "social disease" even though he had not had sexual relations outside of marriage. The gon identified the transgressor. Also, it sometimes happens that a child falls ill and the parents suspect sorcery. They consult the gon to determine who has cast the evil spell. ${ }^{145}$ Recently, missing cellular telephones have become the most common reason that people consult the Zongo gon. ${ }^{146}$

1. Second example of Nigerien traditional law: the gon oracle confirms the identity of a petty thief. ${ }^{147}$

The second gon I witnessed in Zongo was presided over by the Sarkin's younger brother, Boubacar. ${ }^{148}$ When I arrived at the Sarkin's compound preliminary discussions had already taken place and the interested parties had gathered in a courtyard to consult the oracle. ${ }^{149}$ Three young men were present, all who appeared to be in their early to mid twenties, one who had been severely beaten. His clothing was stained with blood, his face had open gashes, and his eyes and lips were badly swollen. There were also two middle-aged men in attendance. Each was dressed in professional garb and, judging by their comportment and their fluency in French, both were educated.

A theft had brought them to Zongo that day. One of the young men maintained an informal business in Niamey selling cigarettes, matches, chewing gum, aspirin, and

\footnotetext{
${ }^{145}$ See Interview with Hamza Maman Bako, supra note 11.

${ }^{146}$ Cell phone us is spreading rapidly in Niger because cellular technology permits the country to leapfrog past its antiquated communications infrastructure.

${ }^{147}$ The entire description is based on Zongo Field Notes 00004, Niamey, Republic of Niger (June 12, 2004).

${ }^{148}$ See supra note 143.

${ }^{149}$ The Sarkin's compound was under construction, which forced this gon from the mud room where the first one had taken place to an uncovered courtyard.
} 
other sundries from a small table that he set up next to a road in his community. Some goods disappeared from his table, and he suspected the bloodied man of taking them. At first, the table seller and his brother (the third young man who was present) took the suspect to the police station where he confessed to the theft and agreed to pay compensation. But on the way back to their neighborhood the suspect changed his mind saying he had confessed only because he was afraid of the police. The retraction, and the anger it caused, led to his beating.

The table seller and his brother offered to resolve the issue by coming to Zongo to consult the gon, and apparently the suspect agreed. The two older men were "witnesses," who had tried to mediate the disagreement back in their community and now had come to participate in the gon.

Two boys - both Koranic students from the Zongo neighborhood studying under marabout Oumarou - began preparing for the gon oracle by rolling out the plastic prayer rug, kneeling to face one another, and peeling off their shirts. The older of the two boys was involved in the first gon, described in Part I.B, above, but the other boy I had not seen before. ${ }^{150}$ The marabout arrived, squatted with his back against a mud wall, and opened his embossed Koran in preparation for reading the yassina.

As the ceremony was about to begin, Boubacar raised with one of the older men the topic of payment. After a brief discussion in Hausa (which I did not understand), he

\footnotetext{
${ }^{150}$ See Zongo Field Notes 00005, Niamey, Republic of Niger (June 14, 2004). The Zongo marabout, Oumarou, reported that presently there are six different boys who hold the reeds for the Zongo gon ceremony. All of them are his Koran students, and none of them receives any special training for the gon. They participate in the gon when they are needed and available, and they do not work in pre-established teams.
} 
turned to address the younger men and, in Zarma, said wo kanda zambar fo, or, "give me 5,000 CFA." 151 One of the young men dug a bill out of his pocket and handed it over. Having collected the fee, Boubacar instructed the three young men to stand. He asked them their names, at which point the younger brother of the table seller nervously told him that "the things that were stolen were not mine, they were his," pointing to the older brother. He looked over his shoulder toward the benches and seemed to be hoping that he would be dismissed from the proceeding. Boubacar replied that he was a part of this too, and that he had nothing to fear so long as they told the truth.

Boubacar then approached the three young men and led the injured one toward the kneeling, shirtless Koran students. He compelled the injured young man to bend at the waist and place his hand between the reeds, which the boys where holding in place with their fingers. As they maintained their positions, Boubacar led the injured man through a recitation in Hausa that was designed to limit the focus on the gon and invoke its power to identify the author of the crime. When Boubacar was done, the marabout began reading the yassina aloud and the boys removed their fingers from the reeds. They immediately bowed inward, indicating that the beaten young man was guilty of the theft. To be certain, Boubacar repeated the entire process. Again, the reeds immediately bent inward. The expression on the beaten young man's face did not change. He waited impassively to be dismissed, and when he was, walked back to his wooden bench and sat down.

\footnotetext{
${ }^{151}$ At that time, 5,000 CFA equaled approximately $\$ 10$, a princely sum in a country where more than half the population lives off of less than one dollar per day. However, the fact that the Sarkin demands payment for the gon is not remarkable from a Nigerien perspective. Custom demands that marabouts and zimas be paid for the services they render. In my experience, there usually is no set fee. The practitioner asks the client to pay whatever he thinks the service is worth. As indicated in note 122, above, I expressed reluctance to pay the Sarkin for the privilege of observing the gon, and by thus heeding my own cultural bias, probably unnecessarily limited my opportunities for direct observation.
} 
Having obtained an answer from the gon, the two young men and the two older men huddled with Boubacar to decide what should be done with the gon evidence. The older men agreed to remonstrate with the thief to compensate the table seller and avoid further trouble. If he refused, they all agreed, they would have to return to the police station to inform the officials that the gon had verified the suspect's guilt.

2. Further observations about the gon

From a Western perspective, perhaps the most surprising feature of the gon oracle is that a broad swath of the population considers it infallible. The parties themselves, including those found culpable, generally accept the gon's determination without protest. In the descriptions provided above, as well as in the third gon that I witnessed, all of the accused parties accepted and admitted their guilt once the gon had spoken. This acceptance was most striking in the first gon example, where the two wives, with their extended families in support, maintained their innocence loudly and angrily until the moment the gon delivered its verdict, at which time each admitted publicly that she had been caught. In fact, in the dozens of descriptions of gon ceremonies I have heard over the years, only two concluded with the identified author of the wrong continuing to deny his guilt. ${ }^{152}$ In both of those cases, in accordance with the traditionally accepted norm of group responsibility for social harms ${ }^{153}$ the families of the accused agreed to compensate the victims in spite of the individuals' continuing denials. ${ }^{154}$

\footnotetext{
${ }^{152}$ Interview with Yaye Iday, Gassangourni Maigari, Hassan Djibou, and Hamidou Gassangourni, Fandou Berri, Republic of Niger (November 14, 2003) (recounting a case where a Fulani herder was accused of stealing livestock but maintained his innocence); Interview with group of villagers, Fandou Berri, (May 22, 2000 (evening)) (recounting an instance where a young man of bad reputation denied stealing money in spite of being found guilty by a gon).

${ }^{153}$ See supra part III.D.2.

${ }^{154}$ Interview with Yaye Iday, Gassangourni Maigari, Hassan Djibou, and Hamidou Gassangourni, supra note 152; Interview with group of villagers (May 22, 2000 (evening)), supra note 152.
} 
In addition to the almost uniform acquiescence of those found guilty by the gon, a broad cross section of Nigeriens, many of whom are aware of Western skepticism about mystical phenomena, offer stories to illustrate its infallibility. According to one such story, a Nigerien man who was living in Cote d'Ivoire many years ago sent a large amount of money back to his natal village in the care of a group of young men. He sent the money with detailed written instructions on how to distribute it, but when village elders attempted to carry out the instructions they found that there was not enough money in the package, and they assumed that the youthful couriers had stolen it. The village chief ordered a gon, which determined that all of the youths were innocent. Later, the man sent apologies from Cote d'Ivoire that he had mistakenly enclosed too little money. To the villagers, this story furnished conclusive proof that the gon would never assign blame incorrectly. ${ }^{155}$

In another testament to the gon's infallibility, my collaborator, Bachir Tidiani, told me with delight that several years ago a television station in Niamey did an investigative report of the Zongo gon to test its accuracy. Station employees fabricated a story about a theft and took it to the Sarkin of Zongo, who approved a reading of the gon. The oracle tested each of the suspects but "trapped" no one, proving its infallibility. ${ }^{156}$

It is a remarkable sign of the gon's widespread acceptance in Nigerien culture that stories endorsing its power and accuracy come from across the socio-economic spectrum. In the numerous cases recounted to me by rural peasant farmers, I have never heard a whisper of doubt that the result of a properly conducted gon is anything other than a verdict handed down directly from God. But unlettered rural people are not the only ones

\footnotetext{
${ }^{155}$ Interview with group of villagers, Fandou Berri, Republic of Niger (May 26, 1996); Kelley, supra note 12 , at 678 and n. 162.

${ }^{156}$ See Chegou, supra note 71 , at 61 (also referring to this story).
} 
who believe in the gon's power to reveal truth in the context of legal disputes. In the second gon example, for example, the witnesses who attended the gon and then participated in negotiating the resolution were educated, sophisticated urbanites. They neither expressed nor exhibited any skepticism about the oracle.

Other highly educated people endorse the gon, often accompanied by a shrug of the shoulders and a statement to the effect of "I don't know how it works, only that it does." One Nigerien man who had earned his $\mathrm{PhD}$ from Boston University recounted a story from his youth in which he was accused of stealing a watch. With his honor at stake, he insisted on consulting the gon oracle. He and his companions found a marabout willing to perform the ceremony, and at the critical moment the reeds bent outward proving his innocence. Based on the gon evidence, his accuser apologized. ${ }^{157}$ Still another highly educated and worldly Nigerien professor told me that when he was a middle school student in Niamey in the early 1960s the teachers from the middle school all of them French nationals - would order a gon performed whenever anything of value disappeared. It never failed to identify the responsible party. ${ }^{158}$

In addition to the deeply held belief in its infallibility, there are practical reasons why Nigeriens rely on the gon. One is that it permits them to steer questions of law and justice toward traditional leaders who are thought to be purer of heart than the distant, foreign and corrupt actors of the state legal system. ${ }^{159}$ Although people in the city sometimes bring their theft accusations and other legal matters to the police, ${ }^{160}$ it is much

\footnotetext{
${ }^{157}$ Interview with Boubacar Assoumi, Niamey, Republic of Niger (December 2, 2003).

${ }^{158}$ Interview with Professor Sidikou Harouna, supra note 35.

${ }^{159}$ See supra notes 113-114 and accompanying text.

${ }^{160}$ As illustrated by the second gon example, the oracle's relationship to the state system of justice can be complex in urban areas where people find themselves in close proximity to the police and courts. Niger's current state law does not permit judges and courts to rely on oracles and other forms of mystical evidence to resolve accusations of theft or other crimes. See supra notes 107-109 and accompanying text. But in
} 
more common for parties, particularly in rural areas, to ignore the state system altogether and rely on legal actors they understand and trust. ${ }^{161}$ The first gon example provides a typical example. There, the parties never considered consulting any state legal authority. The husband who suspected his wives of thieving worked his way through various traditional channels of dispute resolution, consulting with family elders, traditional community leaders, and finally the Zongo gon oracle. Neither he nor any of the many vocal and agitated actors in the dispute ever so much as whispered the possibility of referring the dispute to the state system of justice.

Another practical reason why Nigeriens rely on the gon rather than the state legal system is that the oracle is speedy while the state is not. The gon succeeds in restoring order and harmony to Nigeriens' families and communities in part because it renders justice quickly. Relying on the gon, disputants can make their accusations, resolve vital questions of fact, determine guilt, and negotiate a resolution, all in the course of an afternoon, leaving no time for bitterness and rancor to fester and irreversibly damage the community. ${ }^{162}$ Indeed, in the two gon examples, the accusations, the consultation with the Zongo oracle, and negotiation over resolutions, all took place within the same 24 hour

spite of this prohibition, police, prosecutors, and judges routinely take gon evidence into consideration and often send parties to the gon to determine the author of an alleged wrong. The government itself acknowledges that some state judges "forget" to apply state law and instead base their rulings in petty criminal matters on traditional law. See Mission d'Analyse, supra note 12, at 27. Other judges consciously skirt the prohibition by arguing that the state legal system requires them to attempt conciliation between the parties before pursuing any formal charges. The gon evidence, those judges say, is permitted only as a part of the conciliation phase, whether the judicial officers encourage the parties to seek it out or merely take into consideration as traditional evidence that the parties have already procured. Of course, any distinction between the conciliation phase of a case and the official investigation and prosecution is entirely lost on most Nigeriens. See Interview with Judge Hasimiou, supra note 119 (expressing the view that if irrational evidence helps the parties resolve their disputes in the conciliation phase, so be it).

${ }^{161}$ See Kelley, supra note 12, at 659 (most Nigeriens ignore and avoid state law).

${ }^{162}$ Interview with Garba Sidikou, Chef de Canton of Kouray and Secretary General of the Association of Traditional Chiefs of Niger, Niamey, Republic of Niger (December 17, 2003) (stating that speed is the essence of traditional justice in Niger). 
period. This is in stark contrast to the state legal system, which routinely takes years to resolve the simplest of disputes. ${ }^{163}$

These practical considerations help explain why the gon is popular among Nigeriens seeking justice, but there are also more nuanced reasons why so many choose to rely on it to the exclusion of the state system. From our Western perspective, understanding those subtler reasons is aided if we realize that, though the oracle may in some respects appear to take the place of a Western trial, in fact its role in traditional law is quite different.

Unlike a trial, which takes place after the parties have failed to negotiate a settlement and which ideally represents a final determination of a legal dispute, consulting a gon oracle represents an intermediate stage in a process of negotiating a livable resolution to the dispute. In almost all instances, before seeking out the gon, individuals who feel that they are the victims of wrongs, along with their immediate and extended families, have already attempted to resolve their disputes through negotiation and mediation of the sort described in Part III.D.2, above. Typically, where family elders have failed to resolve the dispute, the parties have sought the intervention of some suprafamily traditional authority, usually a village chief or a respected marabout. ${ }^{164}$ Only after those steps have been exhausted do the parties resort to the gon.

And the consultation with the gon oracle is rarely the end of the process. Typically, the gon results are considered another - if vital and irrefutable - piece of

\footnotetext{
${ }^{163}$ See Interview with Nouhu Sauni, Village Chief of Gassangourni, Gassangourni, Republic of Niger (October 28, 2003) (describing a land dispute that had wended its way through various state forums for a decade, and in which a man who had been jailed had sat in prison for more than a year without a hearing); Mission d'Analyse, supra note 12, at.

${ }^{164}$ As discussed note 160 , above, in the city the police and state justice authorities sometimes constitute an intermediate step.
} 
evidence to be taken into account in the negotiation between the victim, the accused, their families and their community. For example, the first gon example ended with an extended huddle between the elders and a determination that the parties should return to the traditional authorities in their community to negotiate a satisfactory conclusion by which all of the parties could continue to live together in harmony. In the second gon example, the older professional men in attendance filled the role of elders by urging the guilty party to admit his guilt, compensate the victim, and avoid further trouble. In the vast majority of cases, once the gon has conclusively identified the wrongdoer in a legal matter, there follows a relatively brief discussion, facilitated by traditional authority figures, where the wrongdoer and his family agree to pay some combination of material and symbolic compensation to the aggrieved party, and the matter ends there.

Consulting the gon oracle is also unlike a Western trial in that the post-gon resolution of the matter does not involve punishing the identified wrongdoer with a fine or jail at the conclusion of the proceeding. ${ }^{165}$ Instead, the resolution normally involves negotiated compensation for the injured party (oftentimes paid, at least in part, by the wrongdoer's family or lineage group) and a symbolic welcoming of the wrongdoer's family back into the community. ${ }^{166}$ Often, the essence of the resolution prescribed by the

\footnotetext{
${ }^{165}$ There is a vague threat of supernatural sanction from the gon, but the potential for harm seems to be related to the person's purity and honesty in approaching the oracle and appears to have little to do with whether the person is guilty or innocent of the alleged wrong. Due this vague threat of harm parties sometimes confess before submitting to the oracle. See, e.g., Interview with Boubacar Bako, Niamey, Republic of Niger (June 9, 2004) (recounting an instance where a suspected thief confessed to avoid submitting to the gon); Interview with Oumarou Alzuma, supra note 92 (recounting a case involving a stolen cell phone where one person in a group of potential suspects confessed rather than participate in the gon); see also Interview with various elders, Fandou Berri and Gassangourni, Republic of Niger (November 18,2003) (a rural farmer indicating that the gon is so powerful, particularly when combined with blood sacrifice, that it can kill people).

${ }^{166}$ Kelley, supra note 12 , at 677-79.
} 
elders is a combination of an apology and a modus vivendi for the broader community. ${ }^{167}$ The role of the gon is to provide clear, reliable facts that permit the parties, their families, and their communities, to break the logjam and move toward restoration of community harmony.

Finally, although it may be stating the obvious, the gon is popular among the people of Niger because if provides them with a form of law that is organically adapted to the rest of their culture. According to Niger's vibrant traditional beliefs, law, spirituality, and community are considered parts of an undifferentiated whole. ${ }^{168}$ Because Nigerien people view the world in this categorically unified way, the gon and similar forms of "law" that draw upon religion and the spirit realm, and that are geared toward maintenance of community harmony, make perfect sense.

\section{Summary}

Before concluding with some predictions of how the Washington Legal Consensus will play out in Niger and some suggestions about a more appropriate way to carry out reform of Niger's legal system, we review what we have learned thus far.

From the point of view of the Washington Legal Consensus, state law reform in Niger is a long overdue housekeeping project. Niger must reform its law to keep up with changes in technology, business, and evolving conceptions of human rights. It also must eliminate the multifarious legal traditions that operate, largely unregulated and unsupervised, around the country and impose a uniform, predictable legal regime. Without such modernizing changes, Niger will repel capital investment and continue to suffer crushing poverty. According to the legal reformers, this process of burnishing and

\footnotetext{
${ }^{167}$ See id. at 677-679.

${ }^{168}$ See supra note 124 and accompanying text.
} 
updating Niger's law should create no abrupt change in Nigeriens' lives because the country's legal system has been based on Western law (specifically the French variety) since independence.

The picture looks very different from the perspective most Nigeriens. They view Western state law as unappealing and of limited utility not only because it is incomprehensible, inconveniently remote, expensive, slow and corrupt, but because it asks the wrong questions and produces the wrong results. In the realm of petty theft, where we have focused our inquiry, most Nigeriens would wonder how the state system could possibly be confident that it identified the source of the wrong without consulting the spiritual realm. Once the guilty party is identified, state law again moves in the wrong direction. Traditional law demands that the wrongdoer be situated within his extended family group, and that the group have a chance to restore and defend its honor by negotiating a modus vivendi with the rest of the community, including the family of the victim. Focusing the legal inquiry only on the wrongdoer and the legal remedy only on the victim, as the state system does, completely misses the point of restoring harmony to the larger social unit. Finally, the idea of punishing the wrongdoer by carting him off to jail is viewed by most Nigeriens as absurd. Why on earth, they would ask, would you remove that person from the community and thereby injure his family, including his ancestors and his descendants, making permanent the tear in the social fabric?

If the gon and similar legal rites play a central role in Niger's most commonly subscribed system of justice, if it is widely accepted as legitimate and infallible, if it is speedy, if it is perfectly consistent with most peoples' cultural beliefs and practices, and if it is efficacious as a tool for restoring community harmony, does it make sense to 
permit Washington Consensus legal reformers to abruptly eliminate it? That is the question we will briefly explore in the concluding section.

\section{Conclusion}

This paper has described the legal traditions that most people in Niger follow, and has cast doubt on the wisdom of abruptly displacing those traditions by means of Washington Legal Consensus reform. But that does not mean that all attempts to change Niger's law are misguided, or that the West can play no useful role in facilitating the development of Niger's legal system.

The law is not a static. As time passes, the law that Nigeriens live by will change whether or not the change is being pushed by Western legal reformers. ${ }^{169}$ The gon itself illustrates the evolving nature of law, for although we refer to it in this paper as a form of "traditional law," we know that it probably was not widely practiced, at least not in its present form, until the $20^{\text {th }}$ century when Nigerien society as a whole was moving toward an embrace of Islam. There is little doubt that such natural change in the law would continue, even in the absence of Washington Consensus pressure. For example, it seems a safe prediction that over time, if Niger were to increase its rate of literacy and its connections to the global economy, reliance on magio-religious legal practices such as the gon would naturally fade, and more secular and rational legal practices would take root.

If Niger's law is bound to change over time, there is nothing wrong and much right with encouraging movement toward transparency, consistency, predictability, and dedication to human rights. Recent history indicates that such qualities tend to engender

\footnotetext{
${ }^{169}$ See Berry, supra note 65 , at 1.
} 
long-term political stability. ${ }^{170}$ Furthermore, it is at least conceivable that the World Bank and the IMF are right that stable, rational, Western-style laws eventually will spur long-term economic development in Niger, although past experience and present economic indicators provide ample grounds for skepticism. ${ }^{171}$ Finally, if individual and human rights become embedded in Nigerien law, significant portions of the population, most notably women, descendants of slaves, and ethnic minorities, could find their status significantly elevated.

This paper's conclusion, therefore, is not that the Nigerien state should eschew legal reform and leave the resolution of all legal disputes to oracles and the traditional leaders who control them. It is that Nigerien law reformers and their Western sponsors have gone about reform in an unwise fashion. They should pay closer heed to the legal traditions they are displacing, and they should find a way to legitimate the new by affecting a gradual transition. Before outlining a few concrete suggestions for more effective law reform in Niger, I offer a prediction regarding what will happen if the government and its Western sponsors continue down their present Washington Legal Consensus path.

One possibility is that the government of Niger will continue to promulgate Western style laws but not follow through with aggressive steps to end its citizens' reliance on practices such as the gon. If this happens, the Consensus reforms will end up as no more than words on paper, much like the French law that nominally has ruled the

\footnotetext{
${ }^{170}$ See Francis N. Botchway, Good Governance: The Old,The New, The Principle, and the Elements, 13 Fla. J. Int'1 L. 159, 189-96 (Spring 2001) (discussing the connection between democracy and political stability in developing countries); John Linarelli, Peace Building, 24 DENV. J. INT'L \& POL'Y 253, 2567 (Spring 1996) (same).

${ }^{171}$ See supra note 34 and accompanying text (expressing doubt about prospects for economic development).
} 
country since independence. Such a course will accomplish none of its putative goals of creating an attractive environment for capital investment and establishing due process and individual rights, because most people, particularly the uneducated majority living outside of large cities, will simply continue to ignore the state law. If we assume that law reform and modernization is a desirable outcome, then this course will be harmful because it will reinforce the social and cultural gulf that separate the state of Niger and its laws from most of its citizens.

Another possibility is that Niger will carry out its stated plans to aggressively suppress practices such as the gon, as many in the government and the evolue leadership class believe it should. But the consequences of this path will be at least as negative. Communities, particularly rural communities, that exist today under conditions of extreme privation, will suffer. At present they are held together as functioning, sustaining, cooperative social units by means of the gon and other interconnected historical, social, spiritual and legal traditions. If these traditions that resolve rips in the social fabric are suppressed, the Washington Legal Consensus will fail to fill the resulting void, at least in the short and medium term. As discussed in Part III.D.2, above, it will fail for the practical reason that resources do not and will not at any time in the foreseeable future exist to implement Consensus law outside of cities. More fundamentally, it will fail because Nigerien people, even if they could gain access to Western law, would not be willing to rely on it because it is premised on fundamentally foreign and distasteful notions about the nature of law and justice. In sum, my prediction is that eliminating traditional law in Niger will create a void into which social unrest, rather than Western law, will creep. 
For those who wish to encourage Niger to develop a predictable and consistent state legal system but who do not wish to eliminate overnight the traditions that underpin the country's social cohesion, there is another way. It is possible for reformers gradually to create a template for a modern, Western-style legal system while at the same time preserving the legal traditions that work so well for the majority of Niger's contemporary citizens. With this approach, if Niger develops natural or human resources that permit an entrée into the world of global trade, and if as a result of such economic development Niger's citizens and their partners from the West require access to rational, predictable legal structures, they can seek out the state legal system and rely upon it. Likewise, if increased literacy and general education lead to awareness among Niger's people of human rights protections for women and other traditionally disenfranchised groups, then they too can turn toward state law as means of claiming their individual rights and privileges. In short, legal reformers should establish the template of a modern legal system, but should have the patience to let that system compete with traditional law for the allegiance of Niger's people.

How could this gradual, dualistic, competitive approach to legal reform be effectuated? Niger's Washington Consensus reformers could begin by admitting that it is not possible to draft and debate major pieces of legislation meaningfully in a matter of weeks or even months, particularly where the legislation represents a radical departure from existing legal traditions. ${ }^{172}$ As important, reformers should propose that Niger's National Assembly consider legislation to permit state courts to take cognizance of traditional evidence, such as gon evidence, in cases where the stakes are relatively low, as

\footnotetext{
${ }^{172}$ See supra note 35 and accompanying text.
} 
in misdemeanor theft cases, and where the accused and the victim agree to be bound by tradition.

The effort to create continuity between old and new could also be aided by writing a guide to traditional evidence and the resolution of criminal matters. Assuming a description of traditional procedures and practices could be agreed upon, the written collection could act as a sort of grande coutume to guide state judges in cases where application of traditional law was appropriate. ${ }^{173}$

Niger's legal reformers could go a long way toward legitimating their newly passed criminal laws by revisiting their very Western conception of punishment and honoring the country's traditional emphasis on restorative justice. As a concrete example, the law could delineate circumstances under which persons identified as wrongdoers are reinserted into their families and communities rather than punished by removal and imprisonment. ${ }^{174}$

Whatever course Nigerien reformers and their sponsors pursue, they should not continue to do what they have done thus far. They should not assume that they can impose an utterly foreign law on top of an engrained indigenous legal tradition and expect people to pay heed to the transplant. They should understand that they cannot craft appropriate legislation without carefully studying the unwritten law that already exists. Unless Nigerien legal reformers understand and account for indigenous legal practices such as the gon, and unless they look for ways to link the newly reformed laws to existing traditions, they will damage the traditions that act as the foundations of justice

\footnotetext{
${ }^{173}$ See Mission d'Analyse, supra note 12, at 46.

${ }^{174}$ See id. at 54; Interview with Oumarou Rabo Mainassara, supra note 15 (arguing for a nationally consistent "grande coutume").
} 
and peace in their society while rendering it unlikely that their reformed laws will ever be accepted as legitimate. 